\title{
Technical note: Evaluation of standard ultraviolet absorption ozone monitors in a polluted urban environment
}

\author{
E. J. Dunlea ${ }^{1, *}$, S. C. Herndon ${ }^{2}$, D. D. Nelson ${ }^{2}$, R. M. Volkamer ${ }^{1}$, B. K. Lamb ${ }^{3}$, E. J. Allwine ${ }^{3}$, M. Grutter ${ }^{4}$, \\ C. R. Ramos Villegas ${ }^{5}$, C. Marquez ${ }^{6}$, S. Blanco ${ }^{6}$, B. Cardenas $^{6}$, C. E. Kolb ${ }^{2}$, L. T. Molina ${ }^{1}$, and M. J. Molina ${ }^{1}$ \\ ${ }^{1}$ Department of Earth, Atmospheric and Planetary Sciences, Massachusetts Institute of Technology, Bldg. 54, 77 \\ Massachusetts Ave, Cambridge, MA 02139, USA \\ ${ }^{2}$ Aerodyne Research Inc., 45 Manning Road, Billerica MA 01821-3876, USA \\ ${ }^{3}$ Laboratory for Atmospheric Research, Department of Civil and Environmental Engineering, Washington State University, \\ 101 Sload Hall, Spokane Street, Pullman, WA 99164-2910, USA \\ ${ }^{4}$ Centro de Ciencias de la Atmósfera, UNAM, Ciudad Universitaria, 04510 Mexico City, Mexico \\ ${ }^{5}$ Gobierno del Distrito Federal, Agricultura 21, Piso 1, Col. Escandon, Del. M. Hidalgo, CP 11800, Mexico, D.F., Mexico \\ ${ }^{6}$ Centro Nacional de Investigacion y Capacitacion Ambiental-INE, Av. Periférico 5000, Col. Insurgentes Cuicuilco, CP \\ 04530, Mexico, D.F. Mexico \\ *now at: University of Colorado at Boulder, Cooperative Institute for Research in Environmental Sciences, UCB 216, \\ Boulder, CO 80309, USA
}

Received: 5 December 2005 - Published in Atmos. Chem. Phys. Discuss.: 4 April 2006

Revised: 20 July 2006 - Accepted: 26 July 2006 - Published: 1 August 2006

\begin{abstract}
The performance of the EPA Federal Equivalent Method (FEM) technique for monitoring ambient concentrations of $\mathrm{O}_{3}$ via ultraviolet absorption (UV) has been evaluated using data from the Mexico City Metropolitan Area field campaign (MCMA-2003). Comparisons of $\mathrm{UV} \mathrm{O}_{3}$ monitors with open path Differential Optical Absorption Spectroscopy (DOAS) and open path Fourier Transform Infrared (FTIR) spectroscopy instruments in two locations revealed average discrepancies in the measured concentrations between $+13 \%$ to $-18 \%$. Good agreement of two separate open path DOAS measurements at one location indicated that spatial and temporal inhomogeneities were not substantially influencing comparisons of the point sampling and open path instruments. The poor agreement between the $\mathrm{UV} \mathrm{O}_{3}$ monitors and the open path instruments was attributed to incorrect calibration factors for the UV monitors, although interferences could not be completely ruled out. Applying a linear correction to these calibration factors results in excellent agreement of the $\mathrm{UV} \mathrm{O}_{3}$ monitors with the co-located open path measurements; regression slopes of 0.94 to 1.04 and associated $\mathrm{R}^{2}$ values of $>0.89$. A third $\mathrm{UV} \mathrm{O}_{3}$ monitor suffered from large spurious interferences, which were attributed to extinction of UV radiation within the monitor by fine particles $(<0.2 \mu \mathrm{m})$. The overall performance of this
\end{abstract}

Correspondence to: E. J. Dunlea

(edward.dunlea@colorado.edu) particular monitor was poor owing to a combination of interferences from a contaminated particle filter and/or ozone scrubber. Suggestions for improved operation practices of these $\mathrm{UV} \mathrm{O}_{3}$ monitors and recommendations for future testing are made.

\section{Introduction}

Ozone $\left(\mathrm{O}_{3}\right)$ often serves as the benchmark for the overall pollution level of a given airshed and has been designated as a "criteria pollutant" by the United States Environmental Protection Agency (U.S. EPA). The costs of reducing $\mathrm{O}_{3}$ pollution are estimated in the billions of dollars (Leston et al., 2005). For example, a report by the Instituto Nacional de Ecología (INE) in Mexico (McKinley et al., 2003) found that the implementation of several control measures could achieve a $3 \%$ reduction in daily maximum ozone concentration at the cost of approximately two billion dollars. Regulatory action is initiated by the U.S. EPA when measured $\mathrm{O}_{3}$ concentrations in an urban area exceed a certain threshold (see Reynolds et al., 2004, for recent discussion of one-hour and eight-hour averaged daily maxima standards); this is referred to as "non-attainment". Hundreds of U.S. counties are either close to the threshold or already in non-attainment, and it has been suggested that up to half of the non-attainment

Published by Copernicus GmbH on behalf of the European Geosciences Union. 
counties in the U.S. have $\mathrm{O}_{3}$ concentrations in excess of the threshold as a result of measurement interferences (Leston et al., 2005).

The improvement of monitoring of $\mathrm{O}_{3}$ and its precursors was mandated by the 1990 Clean Air Act Amendments (Section 182 (c) (1)) (Demerjian, 2000). The U.S. EPA has developed recommendations for standard measurement techniques and calibration practices (Environmental Protection Agency, 1998; Paur and McElroy, 1979) to ensure the quality of measurements for the criteria pollutants. The Federal Reference Method (FRM) for $\mathrm{O}_{3}$ is a gas-phase ethylenechemiluminescence detector, however, by far the most common technique for determining the ambient concentration of $\mathrm{O}_{3}$ is ultra-violet absorption (UV $\mathrm{O}_{3}$ monitor), which has been designated as a Federal Equivalent Method (FEM). Indeed, $\mathrm{UV} \mathrm{O}_{3}$ monitors account for almost all of the UV monitoring in the U.S. (Leston et al., 2005). Monitoring networks in other countries have also adopted $\mathrm{UV} \mathrm{O}_{3}$ monitors making them the most ubiquitous instruments for $\mathrm{O}_{3}$ monitoring worldwide. Due to the importance of measuring $\mathrm{O}_{3}$ and the widespread use of $\mathrm{UV} \mathrm{O}_{3}$ monitors, it is critical that this measurement technique be accurate, precise, and wellcharacterized.

The technique of UV absorption measurement of $\mathrm{O}_{3}$ has been described elsewhere (Proffitt and McLaughlin, 1983) and only a brief description is included here. Advantages of the UV absorption technique include its relatively low cost and overall reliability. UV $\mathrm{O}_{3}$ monitors employ mercury $(\mathrm{Hg})$ lamps as reliable sources of line UV radiation at $253.65 \mathrm{~nm}$, corresponding closely to the peak in the $\mathrm{O}_{3}$ cross section (Sander et al., 2002). A typical $\mathrm{UV} \mathrm{O}_{3}$ monitor utilizes an ozone-specific scrubber, often manganese dioxide $\left(\mathrm{MnO}_{2}\right)$ on a substrate or heated silver wool, to create an ozone-free air flow for reference. The UV radiation intensity passing through this reference flow is compared to that through a flow of ambient air and the number density of $\mathrm{O}_{3}$ is determined by the straightforward Beer-Lambert absorption equation, which depends on the well-known absorption cross section of the $\mathrm{O}_{3}$ molecule at $253.65 \mathrm{~nm}$ (Sander et al., 2002). Scattering or absorption of UV radiation by ambient aerosols is typically prevented by a $5.0 \mu \mathrm{m}$ Teflon particle filter placed in the inlet to the $\mathrm{UV} \mathrm{O}_{3}$ monitor. These filters must be changed frequently to prevent a buildup of materials which might then catalyze the breakdown of $\mathrm{O}_{3}$ on the filter or release compounds that could absorb UV radiation. These monitors are routinely calibrated by generating a known amount of $\mathrm{O}_{3}$ via $\mathrm{UV}$ photolysis of molecular oxygen in dried/clean air, often ambient air passed through a desiccant and a charcoal filter.

Possible interferences in this measurement technique have been summarized in several recent reviews (Cavanagh and Verkouteren, 2001; Demerjian, 2000; Environmental Protection Agency, 1993; McClenny et al., 2002; Parrish and Fehsenfeld, 2000; Sickles, 1992). Overall, previous evaluations of the performance of $\mathrm{UV}_{3}$ monitors have yielded mixed results. Several studies have shown adequate performance of $\mathrm{UV} \mathrm{O}_{3}$ monitors in comparison to NOchemiluminescence (Ryerson et al., 1998) and spectroscopic (Stevens et al., 1993) instruments (note: neither technique is a FEM method). Alternatively, a number of studies have shown interferences due to scattering of UV radiation by fine particles within the instrument (Arshinov et al., 2002; Leston and Ollison, 2000) and anomalous sensitivity of the manganese dioxide scrubbers to ambient water vapor, causing a discrepancy compared with calibrations typically performed with dry gas (ASTM, 2003; Butcher and Ruff, 1971; Cavanagh and Verkouteren, 2001; Leston et al., 2005; Maddy, 1999; Parrish and Fehsenfeld, 2000). Aromatic hydrocarbons and oxidized or nitrated aromatics are known to absorb UV radiation and are the most likely to be present in sufficient quantities in an urban environment to potentially contribute to this type of interference (Cavanagh and Verkouteren, 2001; Grosjean and Harrison, 1985; Hudgens et al., 1994; Kleindienst et al., 1993; Leston et al., 2005). Overall, there is still a need for field intercomparisons of these $\mathrm{UV} \mathrm{O}_{3}$ monitors, particularly intercomparisons done in urban locations with high $\mathrm{O}_{3}$ concentrations typical of non-attainment conditions (Parrish and Fehsenfeld, 2000).

This study aims to evaluate the performance of several standard $\mathrm{UV} \mathrm{O}_{3}$ monitors during a field measurement campaign in Mexico City during spring of 2003. The Mexico City Metropolitan Area field campaign (MCMA-2003) featured a comprehensive suite of both gas and particle phase instrumentation from numerous international laboratories, including multiple measurements of $\mathrm{O}_{3}$. We utilize this unique data set to assess the performance of these standard monitors in a heavily polluted urban atmosphere, examine possible interferences and make recommendations for advances in testing and operation of these monitors that should be pursued.

\section{Measurements}

Figure 1 provides a map of the MCMA with the locations of the various sites from which measurements will be presented. A more complete description of the MCMA-2003 field campaign is given elsewhere (de Foy et al., 2005a, b; Molina and Molina, 2006). Details of the $\mathrm{O}_{3}$ measurements made at each location are presented in Table 1 and described below; we briefly introduce the sites here. "CENICA", where the campaign was headquartered, receives a mix of fresh pollution from area traffic corridors and aged pollution from more downtown locations. The "La Merced" site is located very near a busy roadway and the La Merced marketplace. The "Pedregal" site is located at an elementary school in an affluent residential neighborhood west of the city center. As a downwind receptor site, Pedregal often has the highest ozone readings in the city. The "Santa Ana" site is located in the small town of Santa Ana just outside of Mexico City to the southwest and up on a mountain ridge above the Mexico City 


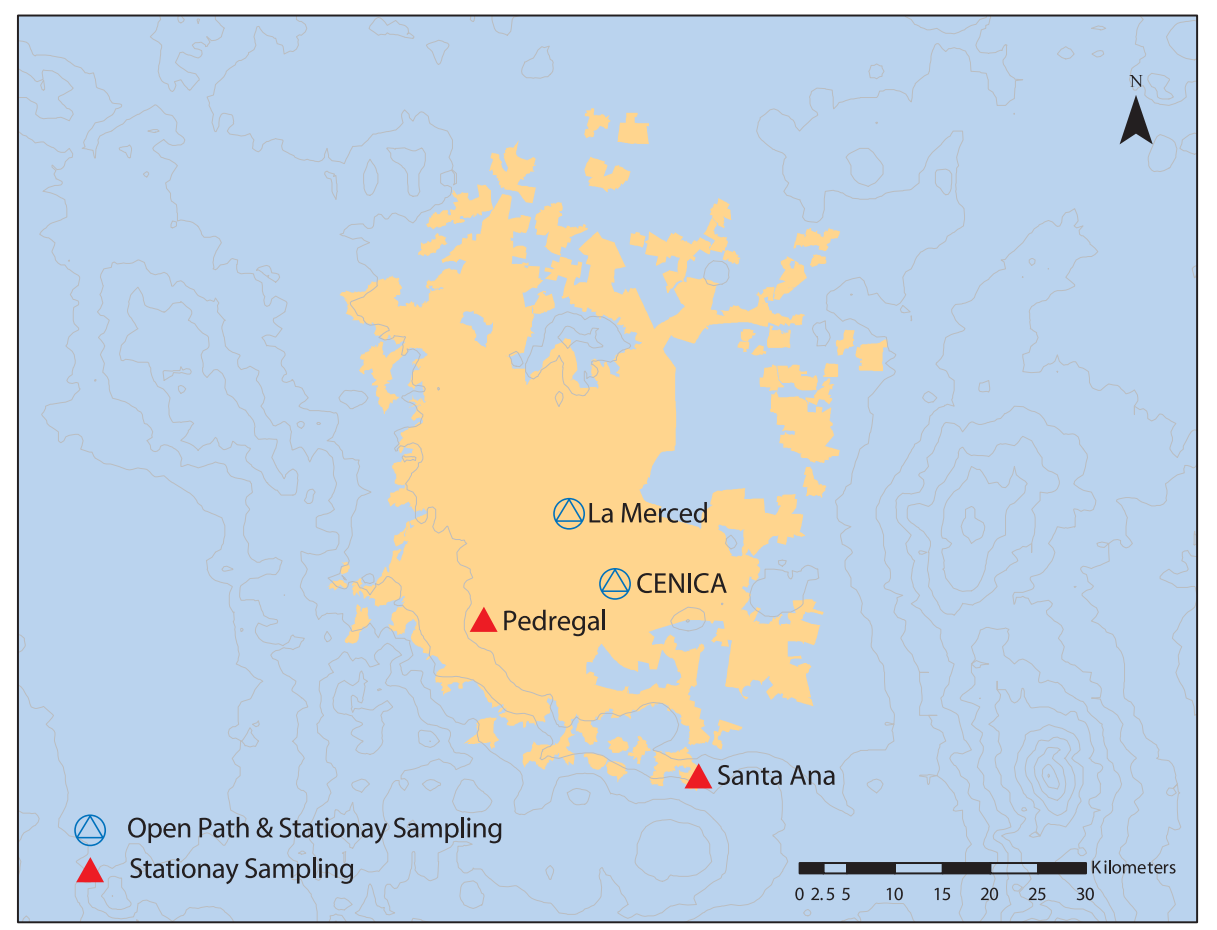

Fig. 1. Map of the Metropolitan Mexico City Area (MCMA). The figure shows the urbanized sections of the city in shaded orange, along with the key topographic contours (grey). The names and locations of the fixed sites described in this work are marked on the map. The open triangles represent points where either the CENICA open path systems or the UNAM open path were located. The filled triangles describe the sites where the Mobile Laboratory was co-located with the stationary sampling $\mathrm{O}_{3}$ monitors. See text (Sect. 2) for a description of the neighborhood and character of each site.

basin floor. Mexico City is surrounded on three sides by mountains (east, south and west); Santa Ana is close to the southern gap in the mountains at Amecameca and receives mostly aged urban air during the day and rural air overnight. The ozone data measured by various instruments located at these sites form the basis of this evaluation; details on these instruments are listed in Table 1.

\subsection{CENICA}

The "supersite" for the MCMA-2003 campaign was located at the headquarters building of the Centro Nacional de Investigacion y Capacitacion Ambiental (CENICA) and included a comprehensive suite of both gas phase and aerosol instrumentation from a number of Mexican, American and European institutions (de Foy et al., 2005a, b; Molina and Molina, 2006). The two-story CENICA building is located on the Iztapalapa campus of the Universidad Autónoma Metropolitana (UAM), to the southeast of the city center (see Fig. 1). For the MCMA-2003 campaign, two research grade long path Differential Optical Absorption Spectroscopy (DOAS) instruments and a research grade long path Fourier Transform Infrared (FTIR) spectrometer were installed on the rooftop of the CENICA building and were operated by groups from the Massachusetts Institute for
Technology (MIT) and Chalmers University of Technology (CTH) respectively. The DOAS technique has been described elsewhere (Platt, 1994). In brief, light from a broadband UV/vis lightsource (Xe-short arc lamp) is projected into the open atmosphere onto a distant array of retro reflectors, which folds the lightpath back into the instrument where spectra are recorded using a Czerny-Turner type spectrometer coupled to a 1024-element PDA detector. For the MCMA-2003 campaign, the DOAS-1 light path was directed towards an antenna tower in a south-easterly direction with a $430 \mathrm{~m}$ path length (total $860 \mathrm{~m}$ ). The DOAS-2 lightpath was directed towards a local hill side of Cerro de la Estrella in a south-westerly direction with a $2.21 \mathrm{~km}$ path length (total $4.42 \mathrm{~km}$ ). Both LP-DOAS instruments measured $\mathrm{O}_{3}$ among other species (Volkamer et al., 1998, 2005b) using ozone's unique specific narrow-band $(<5 \mathrm{~nm})$ absorption structures between 252-262 nm (DOAS-1) and 325-358 nm (DOAS2). Temperature dependent absorption cross-sections (Bass and Paur, 1981) for $293 \mathrm{~K}$ and $313 \mathrm{~K}$ were convoluted to match the spectral resolution of the instruments, and fitted simultaneously with other trace-gas reference spectra and a fifth order polynomial high-pass filter to account for broadband molecule and aerosol extinction using non-linear least squares fitting routines (Fayt and van Roozendael, 2001; Stutz and Platt, 1996). The detection limits for $\mathrm{O}_{3}$ were 
Table 1. Description of relevant details for various $\mathrm{O}_{3}$ instruments employed during this study. See text for further descriptions of site locations. ${ }^{\mathrm{a}}=$ Applicable to UV monitors only.

\begin{tabular}{|c|c|c|c|c|c|c|}
\hline Site & Instrument & Type & $\begin{array}{l}\text { Sampling } \\
\text { height }\end{array}$ & $\begin{array}{l}\text { Distance from } \\
\text { Roadway }\end{array}$ & Scrubber type ${ }^{a}$ & $\begin{array}{l}\text { Absorption } \\
\text { cell material }^{\mathrm{a}}\end{array}$ \\
\hline \multirow[t]{4}{*}{ CENICA } & DOAS-1 & Open Path & $16 \mathrm{~m}$ & $\begin{array}{l}\text { Spanned several } \\
\text { minor roadways }\end{array}$ & - & - \\
\hline & DOAS-2 & Open Path & $70 \mathrm{~m}$ & $\begin{array}{l}\text { Spanned several } \\
\text { major roadways }\end{array}$ & - & - \\
\hline & FTIR & Open Path & $16 \mathrm{~m}$ & $\begin{array}{l}\text { Spanned several } \\
\text { minor roadways }\end{array}$ & - & - \\
\hline & $\begin{array}{l}\text { UV Monitor (Advanced } \\
\text { Pollution Instruments (API) } \\
400)\end{array}$ & Point Sampling & $15 \mathrm{~m}$ & $\begin{array}{l}1000 \mathrm{~m} \text { (minor } \\
\text { roadway) } \\
1500 \mathrm{~m} \text { (major } \\
\text { roadway) }\end{array}$ & $\begin{array}{l}\text { Heated silver } \\
\text { wool } \\
\text { operating } \\
\begin{array}{l}(12 \mathrm{~W}, \\
\left.=70^{\circ} \mathrm{C}\right)\end{array}\end{array}$ & $\begin{array}{l}\text { Quartz tube } \\
\text { and windows }\end{array}$ \\
\hline \multirow[t]{3}{*}{ La Merced } & FTIR & Open Path & $20 \mathrm{~m}$ & $\begin{array}{l}40 \mathrm{~m} \text { (major } \\
\text { roadway) }\end{array}$ & - & - \\
\hline & DOAS & Open Path & $20 \mathrm{~m}$ & $\begin{array}{l}40 \mathrm{~m} \text { (major } \\
\text { roadway) }\end{array}$ & - & - \\
\hline & $\begin{array}{l}\text { UV Monitor (Advanced } \\
\text { Pollution Instruments (API) } \\
400)\end{array}$ & Point Sampling & $6 \mathrm{~m}$ & $\begin{array}{l}10 \mathrm{~m} \text { (major } \\
\text { roadway) }\end{array}$ & Unheated $\mathrm{MnO}_{2}$ & $\begin{array}{l}\text { Quartz tube } \\
\text { and windows }\end{array}$ \\
\hline Pedregal & $\begin{array}{l}\text { UV Monitor (Advanced } \\
\text { Pollution Instruments (API) } \\
\text { 400) }\end{array}$ & Point Sampling & $4 \mathrm{~m}$ & $\begin{array}{l}300 \mathrm{~m} \text { (major } \\
\text { roadway) }\end{array}$ & Unheated $\mathrm{MnO}_{2}$ & $\begin{array}{l}\text { Quartz tube } \\
\text { and windows }\end{array}$ \\
\hline Santa Ana & $\begin{array}{l}\text { UV Monitor (Thermo Envi- } \\
\text { ronmental (TECO) 49-C) }\end{array}$ & Point Sampling & $3 \mathrm{~m}$ & $\begin{array}{l}600 \mathrm{~m} \text { (minor } \\
\text { roadway) }\end{array}$ & Unheated $\mathrm{MnO}_{2}$ & $\begin{array}{l}\text { Aluminum } \\
\text { coated with } \\
\text { Kymar; } \\
\text { Quartz win- } \\
\text { dows }\end{array}$ \\
\hline ARI Mobile Lab & $\begin{array}{l}\text { UV Monitor (Thermo Envi- } \\
\text { ronmental (TECO) 49-003) }\end{array}$ & Point Sampling & $\begin{array}{l}2.4 \mathrm{~m} \text { or } \\
5 \mathrm{~m}\end{array}$ & - & Unheated $\mathrm{MnO}_{2}$ & $\begin{array}{l}\text { Aluminum } \\
\text { coated with } \\
\text { Kymar; } \\
\text { Quartz win- } \\
\text { dows }\end{array}$ \\
\hline
\end{tabular}

$1.3 \mathrm{ppb}$ for DOAS-1 and 5.0 ppb for DOAS-2. This significantly smaller detection limit of DOAS-1 reflects an approximately 20 times larger differential absorption cross section in the wavelength range used by this system. This potential for much more sensitive ozone measurements is partly offset by increasing light extinction from Rayleigh- and Mie scattering at shorter wavelengths, which limits attainable absorption pathlengths and thus detection limits. Also, the broadband light absorption from $\mathrm{O}_{3}$ in the Hartley band reduces the transparency of the atmosphere and may increase photon shot-noise in the spectra. Moreover, different straylight sources gain relative importance in this wavelength range, and need to be corrected for. Finally, the atmospheric oxygen absorption features in the Herzberg band-systems need to be eliminated carefully to allow for highly accurate measurements of ozone by DOAS. We have overcome all the above limitations following the procedure described in Volkamer et al. (1998).
The open-path FTIR system was operated parallel to the DOAS-1 lightpath sampling nearly identical airmasses (same length light path, $<2 \mathrm{~m}$ apart). The FTIR consisted of a medium resolution $\left(1 \mathrm{~cm}^{-1}\right)$ spectrometer (Bomem MB104) coupled to a homemade transmitting and receiving telescope, and provided $\mathrm{CO}$ data (among other species) with $5 \mathrm{~min}$ integration time. Spectra were analyzed using the latest HITRAN database cross sections (Rothman et al., 2003) and a nonlinear fitting algorithm (Samuelsson et al., 2005 ${ }^{1}$ ). The detection limit for the FTIR system was $10 \mathrm{ppb}$.

In addition to the equipment installed for the MCMA-2003 campaign, CENICA maintains a monitoring station located on the roof of its headquarters building, which includes a standard $\mathrm{UV} \mathrm{O}_{3}$ monitor (detection limit $3 \mathrm{ppb}$ ). This UV $\mathrm{O}_{3}$ monitor was calibrated on the same afternoon and via the same standard method as the one on board the ARI Mobile

\footnotetext{
${ }^{1}$ Samuelsson, J., Galle, B., and Mellqvist, J.: personal communication, 2005.
} 
Lab (see Sect. 2.3). The measured values from this monitor were within $7 \%$ of the calibration values, such that the monitor was deemed to be working acceptably and no adjustments were made at that time.

\subsection{La Merced, Pedregal and Santa Ana}

Another featured component of the MCMA-2003 campaign was a measurement site located downtown near the La Merced marketplace; the site is located in close proximity to a busy roadway and $<500 \mathrm{~m}$ from major bus station (TAPO). This site and instrumentation have been described in detail elsewhere (Grutter et al., 2003); briefly, researchers from Universidad Nacional Autónoma de México (UNAM) operated two open path remote sensing instruments: one research grade FTIR and one commercial DOAS system (Opsis AR500). The light paths were run side-by-side between the rooftops of two four-story buildings and were $426 \mathrm{~m}$ long. $\mathrm{O}_{3}$ was measured by both FTIR and DOAS in addition to numerous other compounds; the detection limit for $\mathrm{O}_{3}$ by the FTIR technique was better than 2 ppb (Grutter et al., 2003) and employs the latest HITRAN database cross sections (Rothman et al., 2003). A previous comparison of the $\mathrm{O}_{3}$ reported at $\mathrm{La}$ Merced by this DOAS and the more reliable FTIR instrument (Grutter and Flores, 2004) presented a very high correlation $\left(\mathrm{R}^{2}=0.99\right)$. However, in this study the absolute concentration by the DOAS was consistently lower than that from the FTIR and a correction to the DOAS results was applied accordingly (Flores et al., 2004). The reason for this is unclear and unfortunately, any further discussion of this data is only possible to a very limited extent, as the evaluation procedure employed by the DOAS manufacturer is not clear to us. The open path spectroscopic measurements are dependent on knowledge of the absorption cross section for the molecule being detected. Recent studies have shown that the infrared cross sections of $\mathrm{O}_{3}$ from the HITRAN database, upon which the FTIR open path measurements depend, are up to 5\% too large (PicquetVarrault et al., 2005). Although using this information could bring the comparisons shown below in Sect. 3.2 with the UV $\mathrm{O}_{3}$ monitor into better agreement, it would only partially explain the observed differences of more than $10 \%$, so is not considered important.

The UNAM instruments were in close proximity $(<30 \mathrm{~m})$ to a monitoring station operated by Red Automática de Monitoreo Ambiental (RAMA, 2005). RAMA operates 32 monitoring sites around the Mexico City metropolitan area, 20 of which are equipped with standard $\mathrm{UV} \mathrm{O}_{3}$ monitors, including the La Merced location. The RAMA network has been audited by the U.S. EPA (Environmental Protection Agency, 2003), and was concluded to be "accurate and wellimplemented". In particular, the $\mathrm{O}_{3}$ audit data "were of outstanding quality with no significant bias or imprecision detected across all stations and concentrations audited."

The Pedregal site also housed a RAMA monitoring station including a UV $\mathrm{O}_{3}$ monitor. At the Santa Ana site, re- searchers from CENICA operated a monitoring station that included several criteria pollutant monitors including a UV $\mathrm{O}_{3}$ monitor. Details on these monitors are presented in Table 1 .

\subsection{Aerodyne mobile laboratory}

Another major component of the MCMA-2003 campaign was the Aerodyne Research, Inc. Mobile Laboratory (ARI Mobile Lab), a van equipped with a comprehensive suite of research grade gas and particle phase instrumentation (Kolb et al., 2004), including a UV O 3 monitor. The ARI Mobile Lab was operated in two modes interspersed throughout the five weeks of the MCMA-2003 field campaign - mobile and stationary modes (Kolb et al., 2004). The goals of the mobile mode were to follow specific vehicles to measure their on-road emission ratios and to map out the influence of stationary emission sources. In stationary mode, the ARI Mobile Lab visited the three locations within Mexico City listed in Sect. 2.2 and made continuous measurements at each location for several days in a row. Additionally, the ARI Mobile Lab spent a majority of the nights and several full days during the five week field campaign in the parking lot adjacent to the CENICA building (Sect. 2.1). All instruments included in this study sampled ambient air from the main inlet line of the mobile lab. When moving, this inlet sampled from in the front of the mobile lab at a height of $2.4 \mathrm{~m}$ above the road surface, protruding $1.2 \mathrm{~m}$ from the front bulkhead above the driver seat, resulting in a typical minimum horizontal distance between the inlet and a chased vehicle of at least several meters (Shorter et al., 2005). While stationary, an extension was added to the inlet to sample from a height of $5 \mathrm{~m}$ above the ground. Measured and calculated lag times for all instruments were short $(<10 \mathrm{~s})$ and agreed within $15 \%$ (Herndon et al., 2005).

The UV $\mathrm{O}_{3}$ monitor on board the ARI Mobile Lab was calibrated near the beginning of the field campaign via the EPA standard method by RAMA technicians for continuity of comparisons with RAMA monitors, as all $\mathrm{UV} \mathrm{O}_{3}$ monitors in the RAMA network are routinely calibrated by this method (RAMA, 2005). This calibration procedure involved the use of a charcoal filter for the production of $\mathrm{O}_{3}$ free air in which a known amount of $\mathrm{O}_{3}$ is generated by the photolysis of $\mathrm{O}_{2}$ at $185 \mathrm{~nm}$. The performance of the $\mathrm{O}_{3}$ generator was tracked by the use of a reference $\mathrm{O}_{3}$ monitor maintained in pristine condition in a laboratory. Additionally for the ARI Mobile $\mathrm{Lab} \mathrm{UV}_{3}$ monitor, zero checks were performed several times throughout the campaign by placing a charcoal filter in front of inlet to remove ambient $\mathrm{O}_{3}$; the resulting readings were always near zero (between -4 and $2 \mathrm{ppb}$ ). The detection limit for this $\mathrm{UV} \mathrm{O}_{3}$ monitor was $2 \mathrm{ppb}$. 


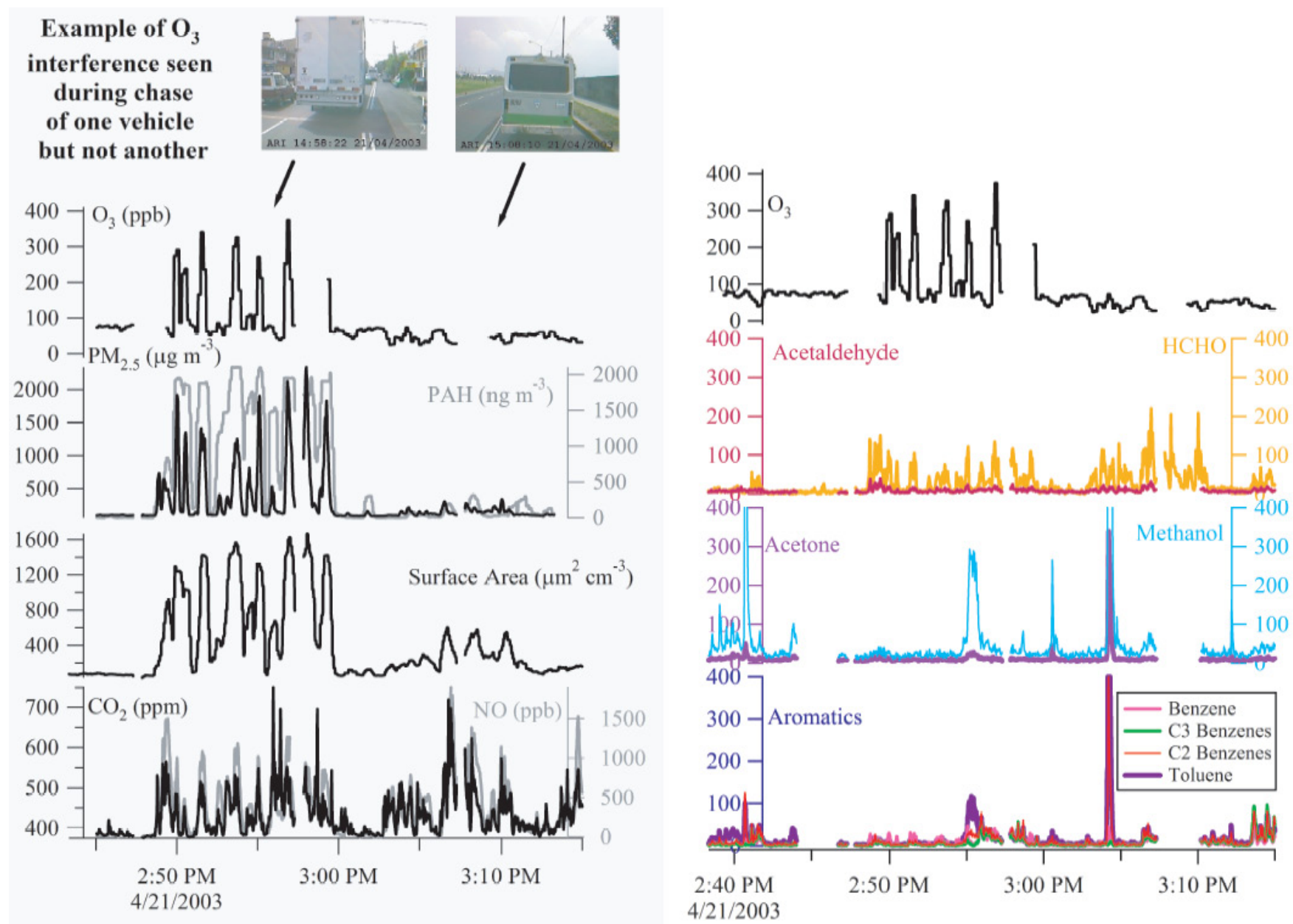

Fig. 2. Two time series showing an interference problem for the $\mathrm{O}_{3}$ instrument on board the ARI Mobile Lab while chasing two separate vehicles. Panels (a) and (b) show same time period with different compounds displayed on each panel. In the first chase of a diesel truck, apparent $\mathrm{O}_{3}$ levels reached up to $400 \mathrm{ppb}$ during obvious combustion plumes; in the second chase of a non-diesel microbus, there was no interference. The $\mathrm{NO}$ signal was derived from a total $\mathrm{NO}_{\mathrm{y}}$ measurement minus measured $\mathrm{NO}_{2}$; it was assumed that all $\mathrm{NO}_{\mathrm{y}}$ in a fresh combustion plume was either $\mathrm{NO}$ or $\mathrm{NO}_{2}$. The $\mathrm{O}_{3}$ interference correlated best with the $\mathrm{PM}_{2.5}$, PAH and particulate active surface area measurements. Measured hydrocarbon levels were low during the diesel event and numerous hydrocarbons (acetone, methanol, benzene, $\mathrm{C} 2-$ benzenes, C3-benzenes, toluene) show a large event at 03:04:11 p.m. with no corresponding interference in the $\mathrm{O}_{3}$ measurement, indicating that these compounds are not responsible for the observed interference. The gaps in the time traces are from deliberate zero air purges of the inlet line. Instrument lag times have been adjusted for such that displayed time traces represent the time at the inlet tip. Instrument response times have not been adjusted.

\section{Results and discussion}

\subsection{Interference from ambient particles for $\mathrm{UV} \mathrm{O}_{3}$ monitor} on board ARI Mobile Lab

During the course of the five week MCMA-2003 campaign, distinct "spike events" in the UV $\mathrm{O}_{3}$ monitor on board the ARI Mobile Lab were observed when the ARI Mobile Lab was sampling the ambient diluted exhaust from on-road diesel vehicles. This $\mathrm{UV} \mathrm{O}_{3}$ monitor registered spikes of up to $400 \mathrm{ppb}$ occurring simultaneously with large increases in $\mathrm{CO}_{2}$ and $\mathrm{NO}$ concentrations from sampled combustion plumes. Figure 2 shows an example of such an $\mathrm{O}_{3}$ spike event while sampling a diesel truck with large particle loadings, but then not present during a chase of a non-diesel microbus just minutes later. More than twenty-five of these events were observed during the MCMA-2003 campaign. All such interference events were coincident with large enhancements in particle number density. Almost all of these events were observed when the ARI Mobile Lab was clearly sampling the exhaust from a diesel vehicle (Canagaratna et al., 2004; Herndon et al., 2005; Shorter et al., 2005); the rest of the events were from indeterminate sources. Of the various instruments on board the ARI Mobile Lab, the best correlations in time for these interferences were found with 
several particle instruments, specifically a DustTrak $\mathrm{PM}_{2.5}$ instrument (TSI Model 8520), which measured the mass loading of particulate matter smaller than 2.5 microns, an EcoChem Polycyclic Aromatic Hydrocarbon (PAH) monitor (PAS $2000 \mathrm{CE}$ ), which measured signal response to photoionization of particulate surfaces and has been shown to respond strongly to surface bound PAHs and possibly to elemental carbon (EC), and an EcoChem Diffusion Charger monitor (DC $2000 \mathrm{CE}$ ), which measures particulate active surface area; see Marr et al. (2004) and Jiang et al. (2005) for a description of the use and interpretation of these instruments while sampling very fresh on-road exhaust emissions. Also on board the ARI Mobile Lab, an Aerodyne Aerosol Mass Spectrometer (AMS) (Jayne et al., 2000) measured size resolved chemical composition of non-refractory particles less than $1 \mu \mathrm{m}$. The AMS showed an increased loading of organic material from diesel vehicles, but no enhancement in nitrate, sulfate or ammonium, consistent with other observed diesel exhaust measurements (Canagaratna et al., 2004). Poor correlations at the time of these $\mathrm{O}_{3}$ interference spikes were found with other gas phase species measured on board the ARI Mobile Lab, including CO, formaldehyde ( $\mathrm{HCHO})$, sulfur dioxide $\left(\mathrm{SO}_{2}\right)$, nitrogen dioxide $\left(\mathrm{NO}_{2}\right)$, and a suite of volatile organic compounds (VOC) measured in real time by an on-board Proton Transfer Reaction Mass Spectrometer (PTRMS) (Rogers et al., 2006). See Fig. 2 for example.

Diesel vehicles are not known to emit $\mathrm{O}_{3}$ directly (Chow, 2001; Yanowitz et al., 2000). The NO concentrations observed in Fig. 2 ( $>500 \mathrm{ppb}$ ) result in a short lifetime for $\mathrm{O}_{3}$ with respect to loss via reaction with $\mathrm{NO}(<6 \mathrm{~s})$; this was shorter than the residence time in the inlet for the $\mathrm{UV} \mathrm{O}_{3}$ monitor inside the ARI Mobile Lab $(\sim 12 \mathrm{~s})$. Thus, if $\mathrm{O}_{3}$ were directly emitted by a diesel vehicle, it would have to be in enormous concentrations ( $>2 \mathrm{ppm}$ per $1 \mathrm{ppm}$ of $\mathrm{CO}_{2}$ emitted) to be observed in the large concentrations in Fig. 2. It is concluded that these large $\mathrm{O}_{3}$ spikes were not due to $\mathrm{O}_{3}$ itself, but rather are due to interferences in the $\mathrm{O}_{3}$ measurement.

Diesel vehicles are known to emit particles with large number densities in both a nanomode, $(0-0.05) \mu \mathrm{m}$, and an accumulation mode, (0.05-0.5) $\mu \mathrm{m}$ (Canagaratna et al., 2004; Kittelson, 1998). A small percentage of particles less than $0.2 \mu \mathrm{m}$ in geometric diameter are known to pass through standard Teflon inlet filters (Liu et al., 1983). Submicron particles may potentially be lost on the mesh scrubber within the $\mathrm{UV} \mathrm{O}_{3}$ monitor (TECO, 2006 ${ }^{2}$ ) and could thus scatter and/or absorb UV light within the detection chamber to appear as a positive $\mathrm{O}_{3}$ signal. This is the simplest, and therefore the most likely, explanation for the large interferences like the example shown in Fig. 2. Fine particles have been shown to cause interferences in $\mathrm{UV} \mathrm{O}_{3}$ monitors in a pre-

\footnotetext{
${ }^{2}$ TECO: Technical Service Group at Thermo Electron Corporation, personal communication, 2006.
}

vious study using a solid dye chemiluminescence monitor (Arshinov et al., 2002), although other studies have not observed this (Huntzicker and Johnson, 1979). Crude estimates of the size of an $\mathrm{O}_{3}$ interference based on the measured active surface area on board the mobile lab are not enough to account for the observed interference, but there is considerable uncertainty in this estimate and the subject warrants further research (see Sect. 4).

Several other possible causes for this observed $\mathrm{O}_{3}$ interference have been discounted. (a) Gas phase compounds emitted by diesel vehicles could be responsible for the interference, however, Fig. 2 shows that large concentrations of $\mathrm{CO}_{2}$, $\mathrm{NO}$ and numerous hydrocarbon species (acetaldehyde, formaldehyde, acetone, methanol, benzene, C2-benzenes, C3-benzenes, toluene) measured on board the ARI mobile lab do not cause such spikes in the $\mathrm{O}_{3}$ concentration. If a gas phase compound were responsible for the interference, it would have to be emitted in large quantities by diesel vehicles only and have a proton affinity less than that for $\mathrm{H}_{2} \mathrm{O}$ such that it would not have been measured by the PTRMS instrument on board the ARI mobile lab. We have no suggestions for likely candidates for such a gas phase diesel emission product. (b) Volatile compounds desorbing off of the particulate filter specifically during sampling of diesel exhaust could also explain these observed interferences, but this would require that the compound or compounds desorb very quickly $(<10 \mathrm{~s})$ in order to cause the short duration spikes observed but not influence the measured $\mathrm{O}_{3}$ background values; see Fig. 2. (c) Rapid fluctuations in water vapor could interfere with the windows of the absorption cell (Wilson, 2005), but it seems unlikely that water vapor levels are much greater in the exhaust of diesel vehicles as compared to that of gasoline vehicles; in fact, the opposite is most likely the case. (d) Lastly, the presence of elemental Mercury could result in spikes in the $\mathrm{O}_{3}$ monitor such as those observed. Although $\mathrm{Hg}$ is known to be sprinkled within vehicles as part of the cultural practices of some Latino groups (Riley et al., 2001), the interference observed in this study was only while sampling the exhaust from diesel vehicles and this cultural practice is not limited to diesel vehicles. In conclusion, none of these possibilities seems as straightforward or as likely as an interference from submicron particles entering the detection chamber within the $\mathrm{UV} \mathrm{O}_{3}$ monitor.

If we take it that fine particles are indeed driving this interference, or at least that the interference is proportional to the concentration of fine particulate matter, the question is whether this type of interference presents a significant issue for most $\mathrm{UV} \mathrm{O}_{3}$ monitors. Sampling done from the ARI Mobile Lab represented an extreme case, with particle loadings often greater than $2000 \mu \mathrm{g} \mathrm{m}^{-3}$, which were heavily dominated by fresh traffic emissions and were thus comprised mostly of fine particles $\left(\mathrm{D}_{p}<0.2 \mu \mathrm{m}\right)$. The interference in the UV $\mathrm{O}_{3}$ monitor on board the ARI Mobile Lab correlated with the $\mathrm{PM}_{2.5}$ particle loading as measured by the DustTrak instrument with a correlation factor was $(0.12-$ 
Table 2. Regression coefficients and corresponding $\mathrm{R}^{2}$ values for linear least square best-fits for standard $\mathrm{UV} \mathrm{O}_{3}$ monitor measured concentrations versus open path DOAS and FTIR measurements at CENICA and La Merced sites. Hourly averaged data used for all instruments. Similar comparisons for CO instruments are included for reference (see Sect. 3.2.1).

\begin{tabular}{|c|c|c|c|}
\hline $\begin{array}{l}\text { (a) } \mathrm{UV} \mathrm{O}_{3} \text { monitor comparison with open path } \\
\text { measurements }\end{array}$ & Regression slope & $\begin{array}{l}\text { Regression intercept (ppb } \\
\text { for } \mathrm{O}_{3} \text { and } \mathrm{ppm} \text { for } \mathrm{CO} \text { ) }\end{array}$ & $\begin{array}{l}\text { Correlation coefficient } \\
\mathrm{R}^{2}\end{array}$ \\
\hline CENICA UV vs. MIT DOAS-1 & 1.08 & 1.1 & 0.97 \\
\hline CENICA UV vs. MIT DOAS- 2 & 1.13 & -4.6 & 0.95 \\
\hline $\begin{array}{l}\text { CENICA UV vs MIT DOAS- } 2 \\
\text { (day time only }=08: 00 \text { a.m. to } 04: 00 \text { p.m.) }\end{array}$ & 1.11 & 1.6 & 0.96 \\
\hline La Merced RAMA UV vs UNAM DOAS & 0.82 & -3.7 & 0.89 \\
\hline La Merced RAMA UV vs UNAM FTIR & 0.90 & -4.4 & 0.96 \\
\hline \multicolumn{4}{|l|}{ (b) Open path DOAS comparison } \\
\hline CENICA DOAS- 2 vs. DOAS- 1 & 0.93 & 5.9 & 0.96 \\
\hline $\begin{array}{l}\text { CENICA DOAS- } 2 \text { vs DOAS- } 1 \\
\text { (day time only }=08: 00 \text { a.m. to } 04: 00 \text { p.m.) }\end{array}$ & 0.96 & 1.8 & 0.98 \\
\hline \multicolumn{4}{|l|}{$\begin{array}{l}\text { (c) CO monitor comparison with open path mea- } \\
\text { surements }\end{array}$} \\
\hline CENICA Monitor vs CTH FTIR & 0.96 & 0.1 & 0.93 \\
\hline La Merced RAMA Monitor vs UNAM FTIR & 0.67 & 0.94 & 0.70 \\
\hline \multicolumn{4}{|l|}{ (d) ARI Mobile Lab UV O 3 monitor comparisons } \\
\hline ARI Mobile Lab UV vs. MIT DOAS- 1 at CENICA & 0.56 & 6.0 & 0.88 \\
\hline $\begin{array}{l}\text { ARI Mobile Lab UV vs. UNAM FTIR at La } \\
\text { Merced }\end{array}$ & 0.47 & 11.6 & 0.90 \\
\hline ARI Mobile Lab UV vs. RAMA UV at Pedregal & 0.60 & 9.0 & 0.90 \\
\hline $\begin{array}{l}\text { ARI Mobile Lab UV vs. CENICA UV at Santa } \\
\text { Ana }\end{array}$ & 0.75 & 0.0 & 0.95 \\
\hline
\end{tabular}

$0.18 \mathrm{ppb}$ ) of $\mathrm{O}_{3}$ interference per $1 \mu \mathrm{g} \mathrm{m}^{-3}$ of particle loading. Ambient loadings typical for many urban environments of $<15 \mu \mathrm{g} \mathrm{m}^{-3}$ would thus lead to a potential interference for a normally situated $\mathrm{UV} \mathrm{O}_{3}$ monitor (at least one that was not on board a mobile laboratory) of $<3 \mathrm{ppb}$. Over the course of an eight hour day in an urban area with a daily maximum $\mathrm{O}_{3}$ concentration of $100 \mathrm{ppb}$, this type of interference could lead to an average measured $\mathrm{O}_{3}$ concentration that is at most $3 \%$ higher than reality. The actual influence of fine particles on the measured $\mathrm{O}_{3}$ concentration by typical UV $\mathrm{O}_{3}$ monitors depends on the placement of the monitors, particularly with respect to fresh traffic emissions. The recently revised national monitoring strategy under development by the U.S. EPA (Environmental Protection Agency, 2005) calls for an increase in the amount of "near roadway" monitoring, which will place more $\mathrm{O}_{3}$ monitors in areas affected by fresh diesel emission. Although this initial indication is that this type of interference may not present a significant problem, this issue is important enough to warrant further study that directly measures the interference to $\mathrm{UV} \mathrm{O}_{3}$ monitors from fine particles in an urban environment (see Sect. 4).
3.2 Overall comparison of multiple $\mathrm{O}_{3}$ measurement techniques

During MCMA-2003, $\mathrm{O}_{3}$ concentrations in Mexico City were observed to exceed $200 \mathrm{ppb}$ on several occasions and exceeded $100 \mathrm{ppb}$ on every day of the 5 week campaign. Thus, the evaluation of the $\mathrm{UV} \mathrm{O}_{3}$ monitors in this setting constituted a test under non-attainment conditions by the U.S. EPA's standards. In this study, the performance of $\mathrm{UV} \mathrm{O}_{3}$ monitors at the CENICA and La Merced sites was evaluated by comparison with co-located DOAS and FTIR open path spectroscopic measurements, which are both nonintrusive and highly accurate techniques in so far as they rely on extensively studied absorption cross sections (Orphal and Chance, 2003). Table 2a lists the results of linear regressions for the $\mathrm{O}_{3}$ concentrations as measured by $\mathrm{UV} \mathrm{O}_{3}$ monitors versus those from the corresponding spectroscopic measurements. The two UV instruments differed from the open path measurements by more than $8 \%$ at each of the CENICA and La Merced sites, however one was systematically higher than the open path determination and the other was lower. The $\mathrm{R}^{2}$ values listed in Table 2 are all $>0.89$. The three most 
probable reasons for divergence from near-perfect agreement were: Sect. 3.2.1: inherent difficulties in comparing open path and point sampling techniques, Sect. 3.2.2: incorrect calibration factors for the $\mathrm{UV} \mathrm{O}_{3}$ monitors, and Sect. 3.2.3: interferences in the $\mathrm{UV} \mathrm{O}_{3}$ monitors. The $\mathrm{UV} \mathrm{O}_{3}$ monitor on board the ARI Mobile Lab (Table 2d) is not included in this assessment for reasons described below in Sect. 3.2.5.

\subsubsection{Comparison of open path and point sampling mea-} surements

The comparison of an open path measurement with a point sampling measurement is inherently difficult owing to the spatial and temporal inhomogeneities within an urban airshed, driven by complex micro-meteorology and/or strong vertical gradients in concentration due to dry deposition. At the CENICA site, the measurements made by the two open path DOAS instruments, which were pointed in different directions and measured at different mean heights and pathlengths, provide an insight into the uniformity of the air mass in the area surrounding the site. The high level of agreement between the two DOAS instruments shown in Table $2 \mathrm{~b}(1 \mathrm{~h}$ averaged points, regression slope $\geq 0.93, \mathrm{R}^{2}=0.96$ ) indicates that $\mathrm{O}_{3}$ is mixed rather homogeneously over a spatial scale of few kilometers near the CENICA site. The regression slope was closer to unity (0.96) when data for this comparison were limited to only daytime hours where atmospheric mixing is strong, which corresponds to the times of highest $\mathrm{O}_{3}$ concentrations with which we are most concerned. We use this comparison of the two DOAS instruments as a way to frame the comparisons between the point sampling and open path instruments; in this light, the comparisons of the point sampling and open path instruments are not as good.

To further put the comparisons of the $\mathrm{O}_{3}$ measurements in context, we also compared the measurements of $\mathrm{CO}$ by point sampling and open path techniques at both the CENICA and La Merced sites; see Table 2c. Because CO is not as reactive as $\mathrm{O}_{3}$ nor as likely to have strong vertical gradients owing to deposition (Stutz et al., 2004), CO should be more homogeneously mixed throughout the boundary layer within the city. At the same time, $\mathrm{CO}$ is a primary pollutant from mobile and other sources and there may be inhomogeneities in close proximity to $\mathrm{CO}$ sources that do not occur for $\mathrm{O}_{3}$. The relatively poor correlation of the $\mathrm{CO}$ monitor at the $\mathrm{La}$ Merced site may be due to an issue with the RAMA CO monitor, which is beyond the scope of this paper to explore. The $\mathrm{R}^{2}$ values for the linear regressions for the CO measurements are thus another indicator of the level of spatial and temporal variation. The $\mathrm{R}^{2}$ values for the $\mathrm{CO}$ measurements were smaller than those for the respective $\mathrm{O}_{3}$ regression plots at both the CENICA and La Merced sites. Thus, our conclusion above is further corroborated that spatial inhomogeneities are small enough to allow meaningful comparisons of hourly averages of open-path and point-sampling $\mathrm{O}_{3}$ measurements at these two locations, particularly for the afternoon periods of elevated ozone concentrations. The next step is to examine why the slopes of the regression analyses deviate from unity.

\subsubsection{Calibration factors for $\mathrm{UV} \mathrm{O}_{3}$ monitors}

Barring interferences (discussed below in Sect. 3.2.3), the slopes of the regression analyses for these comparisons are indicative of the relative calibration factors. We again use the linear regressions for co-located open path DOAS $\mathrm{O}_{3}$ and $\mathrm{CO}$ measurements as points of comparison with the $\mathrm{O}_{3}$ measurements. The open path DOAS $\mathrm{O}_{3}$ and $\mathrm{CO}$ regressions had slopes closer to unity (all within 7\%, except for the La Merced CO comparison, which we are ignoring, see Sect. 3.2.1) than those for the $\mathrm{O}_{3}$ regression plots, indicating better agreement in the relative calibration factors of the two instruments. The slopes of the $\mathrm{O}_{3}$ regression were not as consistent; (1.08-1.13) and (0.82-0.90) for CENICA and La Merced respectively. Intercepts for the $\mathrm{O}_{3}$ regressions with respect to the UV monitors were negligible indicating that the differences in the regression slopes were not skewed by offsets. We therefore conclude that the most probable reason for the discrepancies found is then due to the calibration factors in the $\mathrm{UV} \mathrm{O}_{3}$ monitors.

We now examine the daily patterns of $\mathrm{O}_{3}$ measurements at both locations. The same patterns were observed on all days during the campaign, i.e., the UV monitor at CENICA always reported a higher $\mathrm{O}_{3}$ concentration than the co-located open path instruments and the monitor at La Merced was always lower. Thus, we average data from all days during the campaign together to attempt to quantify the overall trend. Figure $3 \mathrm{a}$ shows that the $\mathrm{UV} \mathrm{O}_{3}$ monitor differs most in absolute concentration from the corresponding spectroscopic measurement at both CENICA and La Merced during afternoons when the $\mathrm{O}_{3}$ concentrations were at their highest. Although the absolute concentration difference (Fig. 3b) varied throughout the course of the day, the percentage difference (Fig. 3c) remained constant from roughly 10:00 a.m. to 05:00 p.m. local time each day, with average values of $+12 \%$ $( \pm 2.5 \%)$ of the ambient $\mathrm{O}_{3}$ concentration for CENICA and $-14 \%( \pm 8.4 \%)$ for La Merced. Note that this is the average of the differences, not the difference of the averages. Overall, in both comparisons, the consistent percentage difference for most of the daytime hours, averaged over the span of a month leads us to the conclusion that the $\mathrm{UV} \mathrm{O}_{3}$ monitors at both sites differed from the co-located open path measurements due to a calibration issue.

This discrepancy in the $\mathrm{UV} \mathrm{O}_{3}$ monitor calibration factors can be corrected for by multiplying the $\mathrm{O}_{3}$ concentrations from the $\mathrm{UV} \mathrm{O}_{3}$ monitors by a constant factor based on the linear regression plots' slopes listed above. Such a correction brings all comparisons with all four open path measurements listed to within $5 \%$ with corresponding $\mathrm{R}^{2}$ values all greater than 0.90; see Table 3. This is excellent agreement in light of the other comparisons shown in Table 2 and previous studies, which have concluded that $\mathrm{UV} \mathrm{O}_{3}$ monitors can measure 

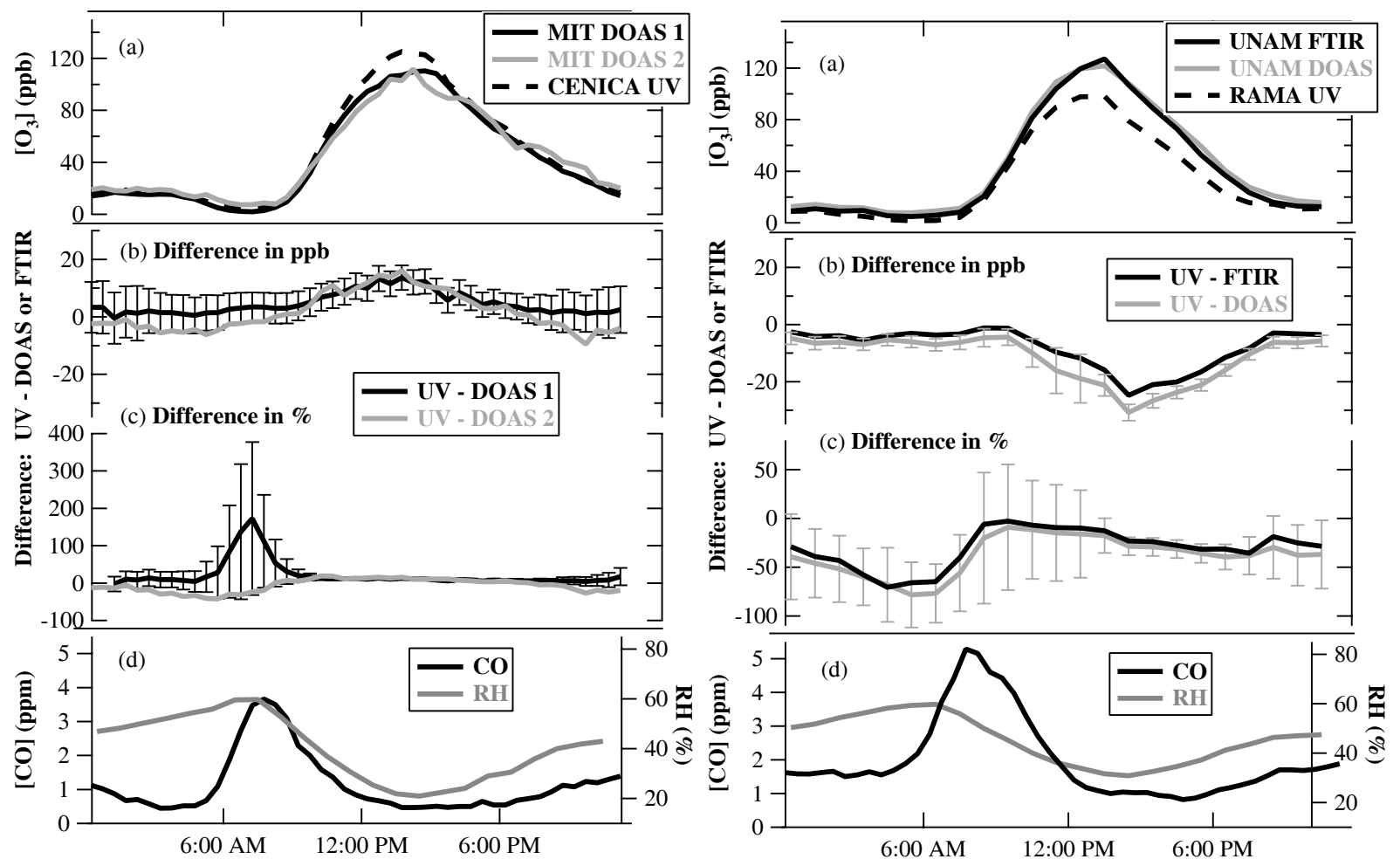

Fig. 3. Diurnally averaged profiles of $\mathrm{O}_{3}$ concentrations for the entire MCMA-2003 field campaign as measured at the CENICA (left panel) and La Merced (right panel) sites are displayed in panel (a). The diurnally averaged profile of the difference between the UV $\mathrm{O}_{3}$ monitor and the corresponding long path spectroscopic measurement are shown on an absolute scale (b) and as a percentage of the measured $\mathrm{O}_{3}$ concentration (c). Note: these are not the differences of the diurnal profiles, they are the diurnal profiles of the differences. The diurnally averaged profiles of the measured CO concentrations and ambient relative humidity at both locations are also shown for reference (d). For the CENICA site, the CO concentration as measured by the CENICA rooftop monitor is shown; for the La Merced site, the CO concentration from the UNAM FTIR instrument is shown. For clarity, $1 \sigma$ uncertainty error bars are placed on only one of traces for differences between UV $\mathrm{O}_{3}$ monitor and corresponding open path spectroscopic measurement (at CENICA uncertainties are displayed for the CENICA UV monitor - DOAS 1; at La Merced for the RAMA UV monitor - UNAM DOAS); the uncertainties for the other difference traces were comparable to those shown.

tropospheric $\mathrm{O}_{3}$ concentrations with uncertainties less than $\pm 3 \%$ (Parrish and Fehsenfeld, 2000).

In practice, $\mathrm{UV}_{3}$ monitors are routinely calibrated by generating a known amount of $\mathrm{O}_{3}$ in a flow of dry zero air and then adjusting the "span" or relative response of the UV $\mathrm{O}_{3}$ monitor to match the calibration standard (Parrish and Fehsenfeld, 2000). The U.S. EPA recommends that calibrations be performed every six months with zero/span checks performed every two weeks with adjustments of the span up to $20 \%$ considered acceptable (Environmental Protection Agency, 1998). Typically, monitoring networks perform calibrations and zero/span checks more frequently, e.g. calibrations every month, and zero/span checks nightly (TCEQ, 2006). UV $\mathrm{O}_{3}$ monitors in the RAMA monitoring network are calibrated every two weeks with span/zero checks performed weekly and allowable span adjustments of $\pm 10 \%$ (RAMA, 2005). Some studies have shown problems in this method arising from the use of dry calibration gas where ambient measurements are made in moist air (Leston et al., 2005; Parrish and Fehsenfeld, 2000), and this is discussed in Sect. 3.2.3. The most likely explanation for the observed differences between the open path and $\mathrm{UV} \mathrm{O}_{3}$ monitors is the resetting of the calibration factors on the $\mathrm{UV} \mathrm{O}_{3}$ monitors as part of routine calibrations. We reiterate that the RAMA network has been audited by the U.S. EPA (Environmental Protection Agency, 2003) and found to be operating well under the guidelines for proper maintenance of their instruments, which indicates that it was the approved calibration procedures that allowed these differences to occur.

\subsubsection{Possible interferences in $\mathrm{UV} \mathrm{O}_{3}$ monitors}

As introduced earlier, several, but not all, previous studies have observed interferences in the $\mathrm{O}_{3}$ concentrations reported by $\mathrm{UV} \mathrm{O}_{3}$ monitors (Arshinov et al., 2002; Huntzicker and Johnson, 1979; Leston et al., 2005). The observed biases 
Table 3. Regression coefficients and corresponding $\mathrm{R}^{2}$ values for linear least square best-fits for corrected standard $\mathrm{UV} \mathrm{O}_{3}$ monitor measured concentrations versus open path DOAS and FTIR measurements at CENICA and La Merced sites. Correction factors determined from regressions slopes listed in Table 2.

\begin{tabular}{llll}
\hline UV O $_{3}$ monitor comparison with open path measurements & $\begin{array}{l}\text { Correction factor } \\
\text { applied to } \mathrm{UV} \mathrm{O}_{3} \\
\text { monitor }\end{array}$ & $\begin{array}{l}\text { Regression slope } \\
\text { CENICA UV vs. MIT DOAS-1 }\end{array}$ & $\begin{array}{l}\text { Correlation coeffi- } \\
\text { cient } \\
\mathrm{R}^{2}\end{array}$ \\
\hline CENICA UV vs. MIT DOAS-2 & 1.1 & 0.94 & 0.90 \\
La Merced RAMA UV vs. UNAM DOAS & 1.18 & 0.96 & 0.89 \\
La Merced RAMA UV vs. UNAM FTIR & 0.92 & 0.99 & 0.97 \\
\hline
\end{tabular}

of the $\mathrm{UV} \mathrm{O}_{3}$ monitors at the two comparison sites in this study, positive at CENICA and negative at La Merced, immediately indicate that a single type of interference in the $\mathrm{UV}_{3}$ monitor was most likely not responsible for both of the observed differences between the monitors and the co-located open path instruments. However, we more thoroughly explore the possibility of interferences in the $\mathrm{UV} \mathrm{O}_{3}$ monitors from (a) tritration of $\mathrm{O}_{3}$ by ambient $\mathrm{NO}$, (b) the presence of gas phase aromatic hydrocarbons and/or their photochemical products, (c) changing ambient relative humidity levels affecting the adsorption/desorption of aromatic compounds onto/from the scrubber in the $\mathrm{UV} \mathrm{O}_{3}$ monitor (Leston et al., 2005) or (d) changing ambient relative humidity levels directly influencing the transmission of UV radiation through the detection cell within the monitor (Wilson, 2005), and (e) particles entering the detection chamber of the monitor (described in Sect. 3.1) or contaminating the particle filter.

(a) The largest percentage differences observed in the diurnal patterns shown in Fig. 3c occur during the morning (05:00 a.m. to 09:00 a.m. local time). We refer to this as "morning rush hour" and examine this period in more depth here briefly. During this period, the $\mathrm{O}_{3}$ concentrations were at their smallest and, as such, were most prone to slight differences between open path and point sampling measurements, in particular the influence of NO and other combustion products. Motor vehicles are the most dominant $\mathrm{NO}_{\mathrm{x}}$ sources in this environment, and at this time of day, the major source of $\mathrm{O}_{3}$ at the surface is the down-mixing of $\mathrm{O}_{3}$ from above. Typical NO concentrations during the morning rush hour were on order of $>100 \mathrm{ppb}$, making the lifetime of $\mathrm{O}_{3}$ with respect to titration by $\mathrm{NO}<30 \mathrm{~s}$. During the morning rush hour, the suppression of the $\mathrm{O}_{3}$ concentration by $40 \%$ to $70 \%$ as measured by the $\mathrm{UV} \mathrm{O}_{3}$ monitor relative to the DOAS-2 open path at CENICA and relative to both open path instruments at La Merced was consistent with both of these $\mathrm{UV} \mathrm{O}_{3}$ monitors being in relatively close proximity to fresh $\mathrm{NO}$ emissions. Thus, $\mathrm{O}_{3}$ as measured at these point sources was titrated by NO to a larger degree than along the open paths used by the spectroscopic techniques, which would have been more greatly influenced by down-mixing of $\mathrm{O}_{3}$ from aloft. Note that the absolute differences in $\mathrm{O}_{3}$ concentration during this morning rush hour time frame were 5 to $7 \mathrm{ppb}$ for these three comparisons, which was only just larger than the combined uncertainties of the pairs of instruments.

The relatively higher amount of $\mathrm{O}_{3}$ measured by the UV $\mathrm{O}_{3}$ monitor at CENICA relative to the DOAS- 1 open path instrument requires a different explanation; this difference in the concentration of $\mathrm{UV} \mathrm{O}_{3}$ monitor minus DOAS- 1 had a maximum of $170 \%$, which corresponds to $3.4 \mathrm{ppb}$ out of $1.9 \mathrm{ppb}$ total $\mathrm{O}_{3}$. We note that combustion sources also peak at this time of day; see Fig. 3d which shows the diurnally averaged profiles of $\mathrm{CO}$ at CENICA and La Merced. The higher concentration of $\mathrm{O}_{3}$ as measured by the $\mathrm{UV} \mathrm{O}_{3}$ monitor could potentially be explained by a small interference, presumably from a combustion product, perhaps fine particles (Sect. 3.1). However, the magnitude of this difference (3.4 ppb) was within the combined uncertainty of the two measurements, so there was no definitive evidence for an interference in the $\mathrm{UV} \mathrm{O}_{3}$ monitor here.

To look at the influence of nearby roadways, we plot the $\mathrm{NO}_{\mathrm{x}}$ concentrations as a function of wind direction in Fig. 4. The CENICA site shows very little variation, whereas the La Merced site shows a large variation of the average $\mathrm{NO}_{\mathrm{x}}$ levels with wind direction. This is consistent with the La Merced measurement site being in closer proximity to a major roadway. Thus, further analysis as a function of wind direction was done on the La Merced data to look at the potential effects of NO tritration. The La Merced data were categorized into three types based on the wind direction with respect to the open path light paths physical relation to the nearby major roadway (see Grutter and Flores, 2004): (A) wind perpendicular to open path measurements (and therefore parallel to roadway, 140 to 230 and 320 to 50 degrees), (B) wind parallel to open path measurements and coming from roadway (50 to 140 degrees), and (C) wind parallel to open path measurements and blowing away from roadway (230 to $320 \mathrm{de}-$ grees). Figure 5 shows that category $\mathrm{B}$ shows enhanced $\mathrm{NO}_{\mathrm{x}}$ as compared to the other directions as expected. Figure 5 


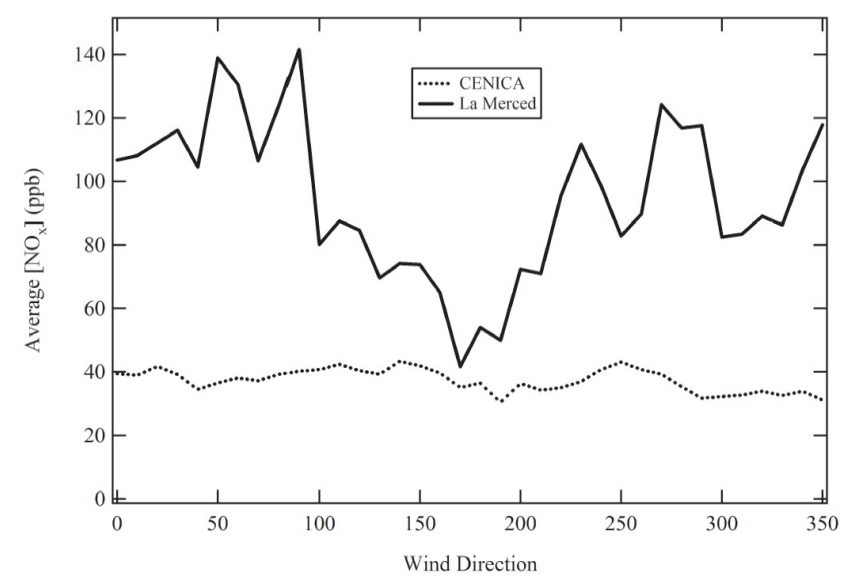

Fig. 4. Average $\mathrm{NO}_{\mathrm{x}}$ concentration as a function of wind direction for CENICA and La Merced sites.

also shows the diurnally averaged profiles for the differences between the UV $\mathrm{O}_{3}$ monitor and FTIR $\mathrm{O}_{3}$ measurements. Although the absolute magnitude of the difference between the measurements varies, the percentage difference remained roughly constant for the majority of the daylight hours (as described above in Sect. 3.2.2 of manuscript) and does not vary systematically as a function of wind direction. Thus, the conclusions is that the difference between the $\mathrm{UV} \mathrm{O}_{3}$ monitor and the open path spectroscopic instruments was not driven by titration of $\mathrm{O}_{3}$ by $\mathrm{NO}$, nor any other combustion product.

Overall, titration of $\mathrm{O}_{3}$ by $\mathrm{NO}$ does affect the diurnal profiles of $\mathrm{O}_{3}$, but does not account for the observed discrepancies between the UV monitors and the open path instruments during the afternoon maxima in $\mathrm{O}_{3}$ concentrations.

(b) A positive interference could potentially occur during periods of high ambient concentrations of aromatic compounds which may adsorb onto the scrubber, causing an apparent increase in $\mathrm{O}_{3}$ concentration (Huntzicker and Johnson, 1979). The MCMA-2003 field campaign included multiple measurements of ambient VOC compounds from several instruments: the two DOAS instruments located at the CENICA supersite, two PTRMS instruments, one of which was on board the ARI Mobile Lab (Knighton et al., 2006??), and canister sampling followed by gas chromatography (GC) analysis at all of the locations described in this study (Lamb et al., 2004; Shirley et al., 2006). These measurements provide a consistent picture that within Mexico City overall loadings of gas phase aromatics were higher during the morning hours (on order of $\sim 30 \mathrm{ppbv}$ ) and lower during the afternoons (on order of $\sim 15 \mathrm{ppbv}$ ). This was inconsistent with the overall pattern of the observed differences between the UV $\mathrm{O}_{3}$ monitors and the open path instruments, which showed a maximum in the afternoon. Additionally, both the DOAS and PTRMS instruments located at the CENICA site observed several large styrene (up to $3.9 \mathrm{ppbv}$ ) and naphthalene (up to $1.9 \mathrm{ppbv}$ ) events during the five week field

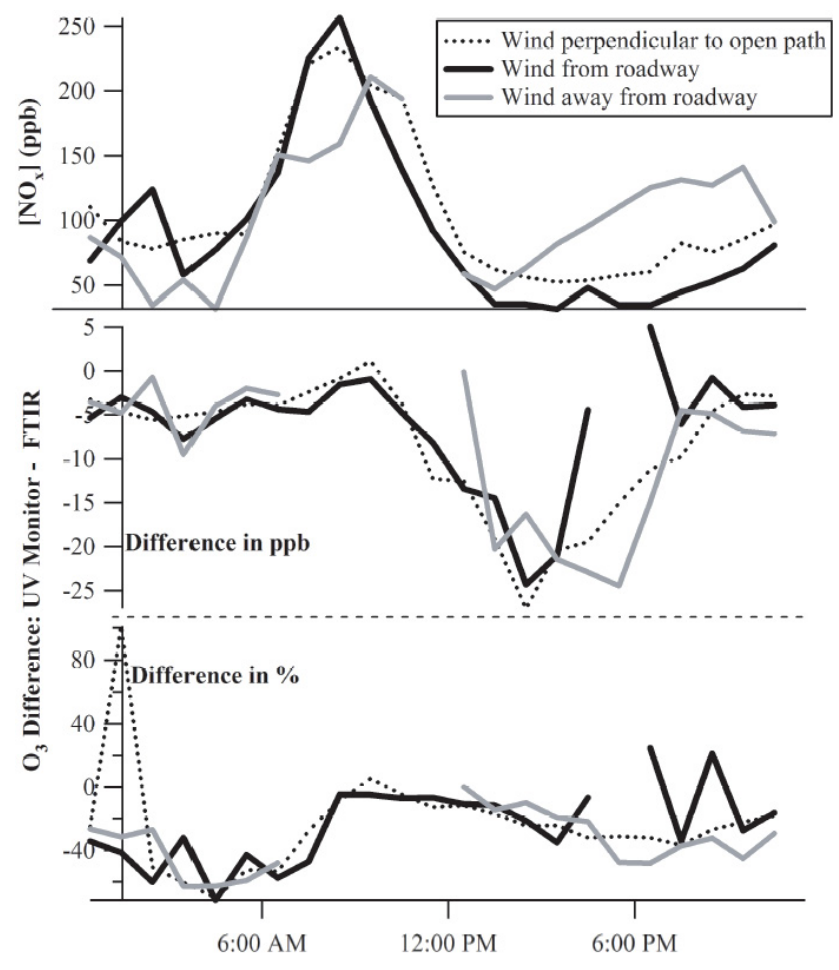

Fig. 5. For La Merced site, diurnally averaged profiles of measured $\mathrm{NO}_{\mathrm{x}}$ concentrations (top) and differences between $\mathrm{UV} \mathrm{O}_{3}$ monitor and open path FTIR measurements in absolute (middle) and percentage (bottom) units colored as a function of wind direction categories (see text for description). $\mathrm{NO}_{\mathrm{x}}$ concentrations from RAMA chemiluminescence monitor.

campaign (Volkamer et al., 2005a). Laboratory tests have shown that $\mathrm{UV} \mathrm{O}_{3}$ monitors respond to both styrene (Grosjean and Harrison, 1985; Hudgens et al., 1994) and naphthalene (Kleindienst et al., 1993), with response factors of (20\%-113\%) and $116 \%$, respectively. Corresponding interferences in the $\mathrm{UV} \mathrm{O}_{3}$ monitors as compared to the DOAS instrument were not observed for these styrene and naphthalene events. We conclude that ambient aromatic hydrocarbons do not significantly influence the measurements made by $\mathrm{UV}_{3}$ monitors.

However, aromatic VOC's are considered less likely to be the primary compounds responsible for interferences in UV $\mathrm{O}_{3}$ monitors than the oxidized and/or nitrated compounds formed from these aromatic VOC's. For example, an EPA laboratory study (Wisbith, 1999) showed that modest levels of o-nitrotoluene ( $24 \mathrm{ppb}$ ) can cause a significant interference at low humidity $(20-30 \%)$. (This same study (Wisbith, 1999) also showed that mercury was a significant interference, but mercury was found only in sporadic short-duration events in Mexico City and would not have been the cause of interferences in the diurnal $\mathrm{O}_{3}$ levels.) The aromatic hydrocarbon concentrations measured during this study were large enough such that the concentrations of oxidized and/or 
nitrated products of these aromatics, which were not directly identified by the VOC measurements made during MCMA2003, might be found in sufficient concentrations to cause an interference as large as the observed difference between the $\mathrm{UV} \mathrm{O}_{3}$ monitors and the co-located spectroscopic instruments. Thus, measured hydrocarbon levels during MCMA2003 provided no evidence for interferences in the UV O monitors from oxidized and/or nitrated aromatic compounds, but did not definitively rule out the possibility.

(c) Previous work by Leston et al. (2005) has shown interferences in the $\mathrm{UV}_{3}$ monitors from aromatic compounds being adsorbed/desorbed onto/from the scrubber coincident with variations in the ambient relative humidity. This interference can be either positive or negative.

A positive interference in the $\mathrm{UV} \mathrm{O}_{3}$ monitor would be expected during periods when the ambient relative humidity was decreasing or relatively stable, which would be from approximately 08:00 a.m. to 05:00 p.m. local time as shown in Fig. 3d, and a positive bias in the $\mathrm{UV} \mathrm{O}_{3}$ monitor was indeed observed at the CENICA site during these times. However, Leston et al. (2005) showed that UV monitors with heated silver wool scrubbers perform well compared with FRM chemiluminescence instruments or, if anything, measure slightly low, whereas UV monitors with $\mathrm{MnO}_{2}$ scrubbers show a positive interference from photochemical products in a smog chamber, presumably aromatic hydrocarbons or their derivatives. In our study however, we observed a positive bias in the UV monitor at the CENICA site, which employed a heated silver wool scrubber and should thus agree well or measure lower values. Additionally, we observed a negative bias in the UV monitor at the La Merced site, which employed a $\mathrm{MnO}_{2}$ scrubber and would thus be prone to positive interferences according to the Leston et al. study. Given that the observed differences at both locations are opposite in sign to the previously reported differences expected from interferences, it is left as our conclusion that the most likely reason behind the observed discrepancies between the UV monitors and the co-located open path spectroscopic instruments is the mis-calibration of the UV monitors.

Additionally along these same lines, a negative interference in the $\mathrm{UV}_{3}$ monitors would be expected as relative humidity rises in the late afternoon and aromatic compounds desorb from the scrubber into the reference channel of the $\mathrm{UV} \mathrm{O}_{3}$ monitor (Leston et al., 2005). However, the negative difference between the $\mathrm{UV} \mathrm{O}_{3}$ monitor and the open path spectroscopic instruments at La Merced occurred during the early afternoon as relative humidity was decreasing.

In summary, we observed no evidence for either a positive or negative interference in the $\mathrm{UV} \mathrm{O}_{3}$ monitors from aromatic compounds being adsorbed/desorbed onto/from the scrubber coincident with variations in the ambient relative humidity. We note that our conclusions generally contradict those of Leston et al. (2005) from their Mexico City study, who observed a difference between co-located UV and chemiluminescence $\mathrm{O}_{3}$ monitors that they attributed to con- tamination of the $\mathrm{O}_{3}$ scrubber in the $\mathrm{UV} \mathrm{O}_{3}$ monitor. The reasons for this contradiction are unclear, but further measurements are suggested at the end of this article.

(d) Careful laboratory studies have shown that variations in relative humidity can interact with the material of the detection cells within the $\mathrm{UV} \mathrm{O}_{3}$ monitors, causing spurious $\mathrm{O}_{3}$ concentration differences during times of rapid changes in ambient relative humidity (Meyer et al., 1991; Wilson, 2005). In this study, the fastest change in ambient relative humidity occurred before 09:00 a.m. local time, which did not correspond with the maximum observed difference between the $\mathrm{UV} \mathrm{O}_{3}$ monitors and the open path spectroscopic instruments which occurred several hours later, typically after 12:00 p.m. local time. Additionally, this afternoon time period of maximum discrepancy in the $\mathrm{UV} \mathrm{O}_{3}$ monitors was coincident with periods of relatively stable ambient relative humidity. Thus, we did not observe any evidence for this interference of changing relative humidity in this field study. We note that other field studies involving co-located measurements of $\mathrm{O}_{3}$ via NO-chemiluminescence and UV absorption on board an airplane have shown no evidence for this effect of ambient relative humidity variations on the scrubber performance (Ryerson et al., 1998).

(e) A possible interference from ambient particles was not substantiated by diurnal profiles of particle mass below $0.2 \mu \mathrm{m}$ from either previous studies (Moya et al., 2004) or from the MCMA-2003 campaign (Salcedo et al., 2006). Fine particles of diameter $<0.2 \mu \mathrm{m}$ reached a maximum mass concentration in Mexico City during the morning hours, but differences between the $\mathrm{UV} \mathrm{O}_{3}$ monitors and the spectroscopic instruments were largest during the afternoon. $\mathrm{PM}_{10}$ measurements at both the CENICA and La Merced sites corroborate this diurnal pattern, also showing maximum particle loadings in the morning (RAMA, 2005). Thus, ambient particles could not have accounted for the observed differences between the $\mathrm{UV} \mathrm{O}_{3}$ monitors and the open path spectroscopic instruments.

\subsubsection{Conclusions on overall comparison of multiple $\mathrm{O}_{3}$} measurement techniques

In conclusion, we observed no evidence for any interference, either positive or negative, in the $\mathrm{UV} \mathrm{O}_{3}$ monitors from the possible sources listed in Sect. 3.2.3. Measurements of ambient hydrocarbons exclude the possibility that aromatic VOC's cause a significant interference in $\mathrm{UV}_{3}$ monitors, but do not preclude the possible influence of oxidized and/or nitrated aromatics. In general, our results do not rule out the possibility of some complex interference accounting for the observed differences between the UV $\mathrm{O}_{3}$ monitors and the open path spectroscopic instruments. However, as detailed in Sect. 3.2.2, the simplest, and therefore most plausible, explanation for the observed differences was the incorrect calibration factors for the UV monitors. 


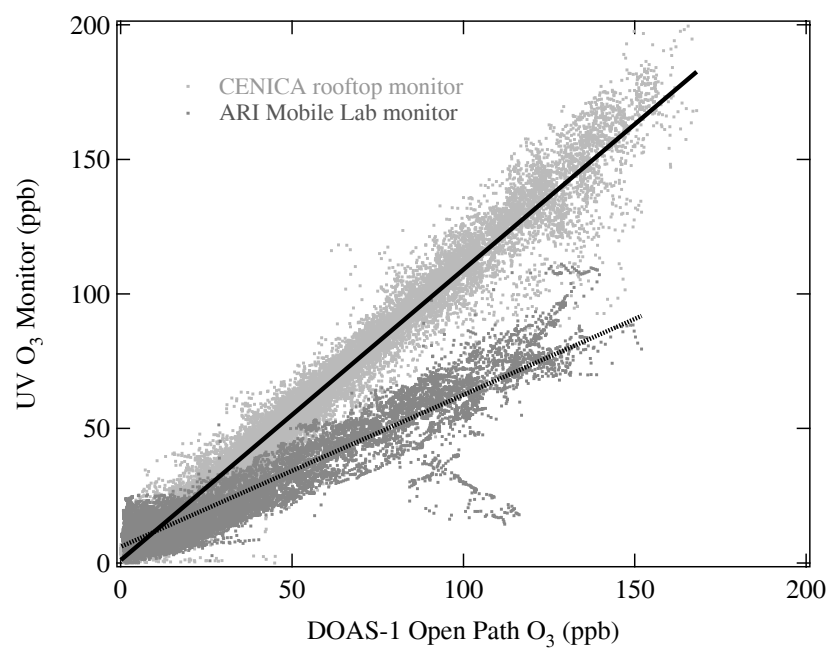

Fig. 6. Linear regressions for $\mathrm{UV} \mathrm{O}_{3}$ monitors versus DOAS-1 open path measurement of $\mathrm{O}_{3}$ at CENICA site. Data from two different $\mathrm{UV} \mathrm{O}_{3}$ monitors are shown: the CENICA monitor located on the roof of their headquarters building (light gray points) and the monitor on board the ARI Mobile Lab (dark gray points). The linear fits (with $2 \sigma$ uncertainties reported from the fit only) are:

CENICA rooftop monitor (solid line): slope $=1.08 \pm 0.01$, intercept $=1.1 \pm 0.1, \mathrm{R}^{2}=0.97$

ARI Mobile Lab monitor (dashed line): slope $=0.56 \pm 0.01$, intercept $=6.0 \pm 0.1, \mathrm{R}^{2}=0.88$.

\subsection{5 $\mathrm{UV} \mathrm{O}_{3}$ monitor on board ARI Mobile Lab}

Comparisons of the data from the $\mathrm{UV} \mathrm{O}_{3}$ monitor on board the ARI Mobile Lab with measurements from DOAS, FTIR and other $\mathrm{UV} \mathrm{O}_{3}$ monitors during stationary deployments at all four co-located sites (Table $2 \mathrm{~d}$ ) revealed a degraded performance for this particular monitor. Figure 6 shows the linear regressions for the $\mathrm{UV} \mathrm{O}_{3}$ monitor on the roof of the CENICA headquarters building and the monitor on board the ARI Mobile Lab versus the co-located DOAS-1 open path measurement. This is an example of the degraded performance of the ARI Mobile Lab monitor, which displayed a negative bias at high ambient $\mathrm{O}_{3}$ levels and a positive bias at low ambient $\mathrm{O}_{3}$ levels. This pattern was observed at all four stationary sites in comparisons with both open path and point sampling $\mathrm{O}_{3}$ measurements, with multiple scrubber types, indicating that the problem was definitely with the $\mathrm{UV} \mathrm{O}_{3}$ monitor on board the ARI Mobile Lab. This behavior may be explained by calibration factor differences but was most likely due to a contaminated particle filter and/or scrubber for this particular monitor. For example, this pattern was consistent with a contaminated particulate filter destroying $\mathrm{O}_{3}$ at high ambient $\mathrm{O}_{3}$ levels and releasing particles and/or some UV absorbing species at low ambient $\mathrm{O}_{3}$ levels. Contamination of this particular particle filter was not surprising given its use on board the ARI Mobile Lab where it directly sampled exhaust plumes from heavy traffic.
Additionally, a negative interference was observed in the $\mathrm{UV} \mathrm{O}_{3}$ monitor on board the ARI Mobile Lab during routine deliberate zero air purges of the main sampling inlet line, which were for calibration of other instruments sampling from the same inlet as the $\mathrm{O}_{3}$ monitor. Recent work has shown that this type of behavior is consistent with rapid relative humidity changes influencing the transmission of UV light within the detection cell of the $\mathrm{UV} \mathrm{O}_{3}$ monitor (Wilson, 2005).

In summary, the performance of standard $\mathrm{UV} \mathrm{O}_{3}$ monitors is dependent upon the performance of the particulate filter, which was definitely an issue during this study for the $\mathrm{UV} \mathrm{O}_{3}$ monitor on board the ARI Mobile Lab. Overall, this particular monitor suffered from both the observed aerosol interference (Sect. 3.1) and from a contaminated particulate filter and/or scrubber, such that data from this monitor were excluded from the earlier comparisons.

\section{Conclusions}

In this study, the performance of several $\mathrm{UV} \mathrm{O}_{3}$ monitors (U.S. EPA Federal Equivalent Method) has been assessed based on data from a recent field campaign in Mexico City. Two of these monitors were co-located with open path DOAS and FTIR measurements of $\mathrm{O}_{3}$. The $\mathrm{O}_{3}$ values determined by these UV monitors were systematically different from those determined by the open path instruments, with averaged discrepancies of up to $18 \%$. If uniform span corrections are applied to these two sets of $\mathrm{UV} \mathrm{O}_{3}$ monitor data, the agreement with the co-located open path instruments is within $5 \%$ with $\mathrm{R}^{2}>0.89$. Comparisons of two co-located open path DOAS $\mathrm{O}_{3}$ measurements and co-located point sampling and open path $\mathrm{CO}$ measurements showed that this level of agreement was adequate for the comparison of a point sampling technique with an open path measurement. Titration of $\mathrm{O}_{3}$ by $\mathrm{NO}$ is shown to influence these comparisons significantly only during morning rush hour when $\mathrm{O}_{3}$ levels were low and $\mathrm{NO}_{\mathrm{x}}$ levels were at their highest. For these two comparisons at the CENICA and La Merced fixed sites, there was no evidence to suggest that the observed differences in measured $\mathrm{O}_{3}$ concentration were due to interferences affecting the reported $\mathrm{O}_{3}$ concentration of the $\mathrm{UV} \mathrm{O}_{3}$ monitors, but such a possibility was not ruled out.

A third $\mathrm{UV} \mathrm{O}_{3}$ monitor employed in this study displayed significant interferences from fresh diesel emissions attributed to fine particles $\left(\mathrm{D}_{p}<0.2 \mu \mathrm{m}\right.$ ) passing through the particulate filter and scattering and/or absorbing radiation within the detection cell. This same monitor also produced biased measurements owing to a contaminated particle filter and/or scrubber.

As discussed in Sect. 3.2.2, the concentration of $\mathrm{O}_{3}$ was overestimated by the $\mathrm{UV} \mathrm{O}_{3}$ monitor at CENICA and was underestimated by the UV monitor at La Merced. As mentioned, we used the regression slopes for the comparisons of 
Table 4. Number of hour-long averaged $\mathrm{O}_{3}$ concentrations that exceeded the EPA's one-hour average threshold of 120 ppb, number of days that included at least one hour-long averaged $\mathrm{O}_{3}$ concentration above this threshold, and number of days that included an eight-hour long averaged $\mathrm{O}_{3}$ concentration above the EPA's eight-hour average threshold of $85 \mathrm{ppb}$. Data are for the different $\mathrm{O}_{3}$ instruments at the CENICA and La Merced sites and are for the days during the MCMA-2003 campaign where the instruments were operating properly (27 days at CENICA and 34 days at La Merced).

\begin{tabular}{llll}
\hline Instrument & $\begin{array}{l}\text { Number of hours } \\
\text { with } 1 \mathrm{~h} \text { average } \\
\text { violations }\end{array}$ & $\begin{array}{l}\text { Number of days } \\
\text { with } 1 \mathrm{~h} \text { average } \\
\text { violations }\end{array}$ & $\begin{array}{l}\text { Number of days } \\
\text { with } 8 \mathrm{~h} \text { average } \\
\text { violations }\end{array}$ \\
\hline CENICA & & & \\
$\mathrm{UV} \mathrm{O}_{3}$ monitor & 55 & 19 & 20 \\
$\mathrm{UV} \mathrm{O}_{3}$ monitor corrected & 37 & 17 & 19 \\
La Merced & & & 11 \\
$\mathrm{UV} \mathrm{O}_{3}$ monitor & 21 & 13 & 19 \\
$\mathrm{UV} \mathrm{O}_{3}$ monitor corrected & 50 & 21 & \\
\hline
\end{tabular}

the $\mathrm{UV} \mathrm{O}_{3}$ monitors with the open path spectroscopic instruments to determine a corrected calibration factor for the UV monitors. To assess the larger implications of these incorrect calibration factors, the number of violations of the U.S. EPA's $\mathrm{O}_{3}$ non-attainment thresholds was determined for the $\mathrm{O}_{3}$ concentrations as measured by the $\mathrm{UV} \mathrm{O} \mathrm{O}_{3}$ monitors for 1-h and 8 -h standards of $120 \mathrm{ppb}$ and $85 \mathrm{ppb}$, respectively (Environmental Protection Agency, 2005; Reynolds et al., 2004); see Table 4. Correcting the calibration factor in the UV monitors resulted in a slight decrease in the number of days with violations at CENICA, $10 \%$ for 1 -h average and $5 \%$ for 8 -h average, and a relatively large increase in the number of days with violations at La Merced, $61 \%$ for 1 $\mathrm{h}$ average and $72 \%$ for 8 -h average. This data were only from the MCMA-2003 campaign and thus represents a limited sample size and limited amount of seasonal variation. However, it is clear that this issue of correct calibration factors can have a major impact on the non-attainment status of a polluted urban area, falsely inflating or deflating the number of violations, potentially by very large amounts.

In summary, we conclude that $\mathrm{UV} \mathrm{O}_{3}$ monitors, if accurately calibrated, have the potential to work well in a heavily polluted urban environment, but that there are significant challenges associated with calibrating and operating these instruments properly. Regardless of new technologies that may become available, use of $\mathrm{UV} \mathrm{O}_{3}$ monitors in monitoring networks worldwide will undoubtedly continue for many years to come, and as such, several advances with respect to testing and operation of these instruments should be pursued:

(1) Previously recommended calibration procedures involving frequent side-by-side comparisons with an $\mathrm{O}_{3}$ instrument that is maintained in good operating order, preferably employing a different measurement technique (Parrish and Fehsenfeld, 2000), should be adopted by routine users of $\mathrm{UV} \mathrm{O}_{3}$ monitors in addition to whatever calibration practices are currently employed. Ide- ally, discrepancies between particular monitors and the reference instrument should be resolved by cleaning and/or realignment of the UV monitor, rather than adjustments of the zero and span on the monitor.

(2) The large interferences observed while sampling diesel vehicles (Sect. 3.1) indicate that fine particles have the potential to cause significant interferences in $\mathrm{UV} \mathrm{O}_{3}$ monitors. Although the results here indicated that this type of interference is likely to be relatively small for most monitors, this issue should be looked at further. First, it should be confirmed that fine particles are indeed the cause of such interferences or whether some other compound emitted by diesel vehicles is responsible. Either way, further quantification of this interference is necessary in order to definitively determine the potential impact of this interference for $\mathrm{UV} \mathrm{O}_{3}$ monitors placed near roadways.

(3) Although this study was able to reach conclusions employing comparisons of the integrated $\mathrm{O}_{3}$ concentration over a long light path with a point sampling measurement, spatial and temporal inhomogeneities necessarily limit the ultimate precision of such comparisons. Future studies could avoid this limitation by comparing UV $\mathrm{O}_{3}$ monitors side-by-side with point sampling spectroscopic instruments. Potential spectroscopic point sampling techniques include tunable infrared laser differential absorption spectroscopy (TILDAS), folded light path FTIR and folded light path UV-DOAS. We encourage future field studies that incorporate point sampling spectroscopic $\mathrm{O}_{3}$ measurement techniques to operate co-located with a standard $\mathrm{UV} \mathrm{O}_{3}$ monitor so as to more definitively evaluate the performance of this standard measurement technique. If possible, comparisons on multiple $\mathrm{UV} \mathrm{O}_{3}$ monitors with different scrubber 
types would discern amongst various $\mathrm{UV}_{3}$ monitor techniques.

(4) Although interferences due to anomalous interactions of relative humidity with the scrubber were not observed in this study, a "wet" calibration procedure and/or a wet/dry test of the scrubber performance that addresses possible interferences owing to varying relative humidity should be developed. New scrubber technology that completely avoids the possibility of these interferences should also be pursued (Cavanagh and Verkouteren, 2001).

Acknowledgements. The authors would like to thank C. Pastor for creating Fig. 1; J. Samuellson, J. Mellqvist, B. Galle, J. Jayne, P. Mortimer, T. Onasch and D. Worsnop for sharing data; J. C. Wormhoudt, F. San Martini, L. Marr, B. Knighton and L. Earle for helpful discussions; and especially the CENICA staff for hosting the MCMA-2003 field campaign. M. Grutter would like to thank R. Basaldud and E. Flores for their support in the measurements at the Merced site, and CONACYT (J33620-T) and MIT-CAM for the financial support. Financial support from Comision Ambiental Metropolitana (Mexico), the National Science Foundation (ATM-308748 and ATM-0528170) and the Department of Energy (Award DE-FG02-05ER63980 and DEFG02-05ER63982) is gratefully acknowledged.

Edited by: U. Pöschl

\section{References}

Arshinov, M. Y., Belan, B. D., Krasnov, O. A., Kovalevskii, V. K., Pirogov, V. A., Plotnikov, A. P., Tolmachev, G. N., and Fofonov, A. V.: Comparison of ultraviolet and chemiluminescent ozonometers, Atmos. Oceanic Opt., 15(8), 656-658, 2002.

ASTM: Standard Test Methods for Continuous Measurement of Ozone in Ambient, Workplace, and Indoor Atmospheres (Ultraviolet Absorption), Annual Book of ASTM Standards, American Society of Testing and Materials International, 2003.

Bass, A. M. and Paur, R. J.: UV Absorption Cross-Sections for Ozone - the Temperature-Dependence, J. Photochem., 17, 141$141,1981$.

Butcher, S. and Ruff, R. E.: Effect of Inlet Residence Time on Analysis of Atmospheric Nitrogen Oxides and Ozone, Anal. Chem., 43(13), 1890, 1971.

Canagaratna, M. R., Jayne, J. T., Ghertner, A., Herndon, S. C., Shi, Q., Jimenez, J. L., Silva, P., Williams, P., Lanni, T., Drewnick, F., Demerjian, K. L., Kolb, C. E., and Worsnop, D. R.: Chase Studies of Particulate Emissions from in-use New York City Vehicles, Aerosol Sci. Technol., 38(6), 555-573, 2004.

Cavanagh, R. R. and Verkouteren, R. M.: Improving the Scientific Basis for Informed Decisions on Atmospheric Issues, NISTNOAA-Industry Workshop on Atmospheric Measures and Standards, National Institute of Standards and Technology, 2001.

Chow, J. C.: Diesel Engines: Environmental Impact and Control - A Critical Review Introduction, J. Air Waste Manage. Assoc., 51, 807-808, 2001.

de Foy, B., Caetano, E., Magaña, V., Zitácuaro, A., Cardenas, B., Retama, A., Ramos, R., Molina, L. T., and Molina, M. J.: Mexico
City basin wind circulation during the MCMA-2003 field campaign, Atmos. Chem. Phys., 5, 2267-2288, 2005a.

de Foy, B., Molina, L. T., Molina, M. J., Caetano, E., Magaña, V., and Zitácuaro, A.: Meteorological and Photochemical Conditions during the MCMA-2003 Field Campaign, Atmos. Chem. Phys. Discuss., 5, 2503-2558, 2005 b.

Demerjian, K. L.: A review of national monitoring networks in North America, Atmos. Environ., 34, 1861-1884, 2000.

Environmental Protection Agency, U.S.: Air Quality Criteria for Oxides of Nitrogen, Office of Research and Development, 1993.

Environmental Protection Agency, U.S.: Quality Assurance Handbook for Air Pollution Measurement Systems; Volume II: Part 1; Ambient Air Quality Monitoring Program Quality System Development, Office of Air Quality Planning and Standards, http: //www.epa.gov/ttn/amtic/files/ambient/qaqc/redbook.pdf, 1998.

Environmental Protection Agency, U.S.: US EPA Audit of RAMA Network, http://www.sma.df.gob.mx/sma/download/ archivos/auditoria_epa_ingles.pdf, 2003.

Environmental Protection Agency, U.S.: National Ambient Air Monitoring Strategy, Office of Air Quality Planning and Standards, http://www.epa.gov/ttn/amtic/files/ambient/monitorstrat/ naamstrat2005.pdf, 2005.

Fayt, C. and van Roozendael, M.: WinDoas 2.1 Software User Manual, 2001.

Flores, E., Grutter, M., Galle, B., Mellqvist, J., Samuelsson, J., Knighton, B., Jobson, B. T., Volkamer, R., Molina, L. T., and Molina, M. J.: American Geophysical Union Fall Meeting, EOS Trans., 85 (47), Abstract A11A-0003, 2004.

Grosjean, D. and Harrison, J.: Response of Chemiluminescent NOx Analyzers and Ultraviolet Ozone Analyzers to Organic Air Pollutants, Environ. Sci. Technol., 19(9), 862, 1985.

Grutter, M. and Flores, E.: Air pollution monitoring with two optical remote sensing techniques in Mexico City, SPIE, Proceedings of SPIE, 2004.

Grutter, M., Flores, E., Basaldud, R., and Ruiz-Suarez, L. G.: Openpath FTIR spectroscopic studies of the trace gases over Mexico City, Atmos. Ocean. Opt., 16, 232-236, 2003.

Herndon, S. C., Shorter, J. H., Zahniser, M. S., Wormhoudt, J., Nelson, D. D., Demerjian, K. L., and Kolb, C. E.: Real-Time Measurements of $\mathrm{SO}_{2}, \mathrm{H}_{2} \mathrm{CO}$ and $\mathrm{CH}_{4}$ Emissions from In-Use Curbside Passenger Buses in New York City Using a Chase Vehicle, Environ. Sci. Technol., 39, 7984-7990, 2005.

Hudgens, E. E., Kleindienst, T. E., MeElroy, F. F., and Ollison, W M.: A Study of Interferences in Ozone UV and Chmiluminescence Monitors, Measurement of Toxic and Related Air Pollutants, Air Waste Manage. Assoc., 405, 1994.

Huntzicker, J. J. and Johnson, R. L.: Investigation of an Ambient Interference in the Measurement of Ozone by Ultraviolet Absorption Photometry, Environ. Sci. Technol., 13(11), 1414-1416, 1979.

Jayne, J. T., Leard, D. C., Zhang, X., Davidovits, P., Smith, K. A., Kolb, C. E., and Worsnop, D. R.: Development of an Aerosol Mass Spectrometer for Size and Composition Analysis of Submicron Particles, Aerosol Sci. Technol., 33(1-2), 49-70, 2000.

Jiang, M., Marr, L. C., Dunlea, E. J., Herndon, S. C., Jayne, J. T., Kolb, C. E., Knighton, W. B., Rogers, T. M., Zavala, M., Molina, L. T., and Molina, M. J.: Mobile laboratory measurements of black carbon, polycyclic aromatic hydrocarbons and other vehicle emissions in Mexico City, Atmos. Chem. Phys., 5, 3377- 
3387,2005 ,

http://www.atmos-chem-phys.net/5/3377/2005/.

Kittelson, D.: Engines and Nanoparticles: A Review, J. Aerosol Sci., 29, 575-588, 1998.

Kleindienst, T. E., Hudgens, E. E., Smith, D. F., MeElroy, F. F., and Bufalini, J. J.: Comparison of Chemiluminescence and Ultraviolet Ozone Monitor Responses in the Presence of Humidity and Photochemical Pollutants, J. Air Waste Manage. Assoc., 13, 213, 1993.

Kolb, C. E., Herndon, S. C., Mcmanus, J. B., Shorter, J. H., Zahniser, M. S., Nelson, D. D. J., Jayne, J. T., Canagaratna, M. R., and Worsnop, D. R.: Mobile Laboratory with Rapid Response Instruments for Real-Time Measurements of Urban and Regional Trace Gas and Particulate Distributions and Emission Source Characteristics, Environ. Sci. Technol., 38, 5694-5703, 2004.

Lamb, B. K., Velasco, E., Allwine, E., Pressley, S., Westberg, H., Knighton, B., Rogers, T., Grimsrud, E., Jobson, T., Alexander, M., Prazeller, P., Volkamer, R., de Foy, B., Molina, L. T., Molina, M. J., Grutter, M., Bueno, E., Blanco, S., Wohrnschimmel, H., Cardenas, B., Arriaga, J. L., Limon, M. T., Escalona, S., Iglesias, G. S., Doskey, P., and Gaffney, J. S.: Ambient VOC Concentration and Emission Measurements during the MCMA 2002 and 2003 Field Campaigns, Eos Trans. AGU, 85, 47, Fall Meet. Suppl., Abstract A13E-01, 2004.

Leston, A. R. and Ollison, W. M.: The impact of ambient aerosols on ozone as measured by ultraviolet photometry, Proceedings of the AWMA Specialty Conference, Measurement of Toxic and Related Air Pollutants, Air Waste Manage. Assoc., Pittsburgh, PA, 2000.

Leston, A. R., Ollison, W. M., Spicer, C. W., and Satola, J.: Potential Interference Bias in Ozone Standard Compliance Monitoring, J. Air Waste Manage. Assoc., 55, 1464-1472, 2005.

Liu, B., Pui, D., and Rubow, K.: Characteristics of air sampling filter media, Marple VA, L. B., Aerosols in the mining and industrial work environments, Ann Arbor Science, 1983.

Maddy, J. A.: Evaluating a Heated Metal Scrubber's Effectiveness in Preventing Ozone Monitor Anomalous Behavior during Hot and Humid Ambient Sampling, Proceeding of the Air \& Waste Management Association 91st Annual Meeting, 1999.

Marr, L. C., Grogan, L. A., Hohrnschimmel, H., Molina, L. T., Molina, M. J., Smith, T. J., and Garshick, E.: Vehicle Traffic as a Source of Particulate Polycyclic Aromatic Hydrocarbon Exposure in the Mexico City Metropolitan Area, Environ. Sci. Technol., 38(9), 2584-2592, 2004.

McClenny, W. A., Williams, E. J., Cohen, R. C., and Stutz, J.: Preparing to Measure the Effects of the $\mathrm{NO}_{\mathrm{x}}$ SIP Call - Methods for Ambient Air Monitoring of $\mathrm{NO}, \mathrm{NO}_{2}, \mathrm{NO}_{\mathrm{y}}$, and Individual $\mathrm{NO}_{\mathrm{Z}}$ Species, J. AirWaste Manage. Assoc., 52, 542-562, 2002.

McKinley, G., Zuk, M., Hojer, M., Avalos, M., González, I., Hernández, M., Iniestra, R., Laguna, I., Martínez, M. Á., Osnaya, P., Reynales, L. M., Valdés, R., and Martínez, J.: Final Report of the Second Phase of the Integrated Environmental Strategies Program in Mexico, The Local Benefits of Global Air Pollution Control in Mexico City, Instituto Nacional de Ecología, México Instituto Nacional de Salud Publica, México, http://www.ine.gob. $\mathrm{mx} /$ dgicurg/cclimatico/download/benloc.pdf, 2003.

Meyer, C. P., Elsworth, C. M., and Galbally, I. E.: Water vapor interference in the measurement of ozone in ambient air by ultraviolet absorption, Rev. Sci. Inst., 62, 223-228, 1991.

Molina, L. T. and Molina, M. J.: Air Pollution in Megacities, http: //mce2.org/megacities/, 2006.

Moya, M., Grutter, M., and Baez, A.: Diurnal variability of sizedifferentiated inorganic aerosols and their gas-phase precursors during January and February of 2003 near downtown Mexico City, Atmos. Environ., 38, 5651-5661, 2004.

Orphal, J. and Chance, K.: Ultraviolet and visible absorption crosssections for HITRAN, J. Quant. Spectros. Radiat. Transfer, 82, 491-504, 2003.

Parrish, D. D. and Fehsenfeld, F. C.: Methods for gas-phase measurements of ozone, ozone precursors and aerosol precursors, Atmos. Environ., 34, 1921-1957, 2000.

Paur, R. J. and McElroy, F. F.: Technical Assistance Document for the Calibration of Ambient Ozone Monitors, United States Environmental Protection Agency, http://www.epa.gov/ttn/amtic/ files/ambient/criteria/reldocs/4-79-057.pdf, 1979.

Picquet-Varrault, B., Orphal, J., Doussin, J.-F., Carlier, P., and Flaud, J. M.: Laboratory Intercomparison of the Ozone Absorption Coefficients in the Mid-infrared $(10 \mu \mathrm{m})$ and Ultraviolet (300-350 nm) Spectral Regions, J. Phys. Chem., 109(6), 10081014, 2005.

Platt, U.: Chapter 2, Sigrist, M. W., Monitoring by Spectroscopic Techniques, Wiley \& Sons, 1994.

Proffitt, M. H. and McLaughlin, R. J.: Fast-response dualbeam UVabsorption ozone photometer suitable for use on stratospheric balloons, Rev. Sci. Inst., 54, 1719-1728, 1983.

RAMA: Red Automatica de Monitoreo Atmosferico, http://148. 243.232.103/imecaweb/base_datos.htm, 2005.

Reynolds, S. D., Blanchard, C. L., and Ziman, S. D.: Understanding the Effectiveness of Precursor Reductions in Lowering 8-Hr Ozone Concentrations - Part II. The Eastern United States, J. Air Waste Manage. Assoc., 54, 1452-1470, 2004.

Riley, D. M., Newby, C. A., Leal-Almeraz, T. O., and Thomas, V. M.: Assessing Elemental Mercury Vapor Exposure from Cultural and Religious Practices, Environ. Health Perspect., 109(8), 779784, 2001.

Rogers, T. M., Grimsrud, E. P., Herndon, S. C., Jayne, J. T., Kolb, C. E., Allwine, E., Westberg, H., Lamb, B. K., Zavala, M., Molina, L. T., Molina, M. J., and Knighton, W. B.: On-road measurements of volatile organic compounds in the Mexico City metropolitan area using proton transfer reaction mass spectrometry, Int. Jour. of Mass Spec., 252, 26-37, 2006.

Rothman, L. S., Barbe, A., Benner, D. C., Brown, L. R., CamyPeyret, C., Carleer, M. R., Chance, K., Clerbaux, C., Dana, V., Devi, V. M., Fayt, A., Flaud, J. M., Gamache, R. R., Goldman, A., Jacquemart, D., Jucks, K. W., Lafferty, W. J., Mandin, J. Y., Massie, S. T., Nemtchinov, V., Newnham, D. A., Perrin, A., Rinsland, C. P., Schroeder, J., Smith, K. M., Smith, M. A. H., Tang, K., Toth, R. A., Vander Auwera, J., Varanasi, P., and Yoshino, K.: The HITRAN molecular spectroscopic database: edition of 2000 including updates through 2001, J. Quant. Spectros. Radiat. Transfer, 82, 5-44, 2003.

Ryerson, T. B., Buhr, M. P., Frost, G. J., Goldan, P. D., Holloway, J. S., Hübler, G., Jobson, B. T., Kuster, W. C., McKeen, S. A., Parrish, D. D., Roberts, J. M., Sueper, D. T., Trainer, M., Williams, J., and Fehsenfeld, F. C.: Emissions lifetimes and ozone formation in power plant plumes, J. Geophys. Res., 103(D17), 22569 22 584, doi:10.1029/98JD01620, 1998. 
Salcedo, D., Onasch, T. B., Dzepina, K., Canagaratna, M. R., Zhang, Q., Huffman, J. A., DeCarlo, P. F., Jayne, J. T., Mortimer, P., Worsnop, D. R., Kolb, C. E., Johnson, K. S., Zuberi, B., Marr, L. C., Volkamer, R., Molina, L. T., Molina, M. J., Cardenas, B., Bernabe, R. M., Marquez, C., Gaffney, J. S., Marley, N. A., Laskin, A., Shutthanandan, V., Xie, Y., Brune, W., Lesher, R., Shirley, T., and Jimenez, J. L.: Characterization of Ambient Aerosols in Mexico City during the MCMA-2003 Campaign with Aerosol Mass Spectrometry: Results at the CENICA Supersite, Atmos. Chem. Phys., 6, 925-946, 2006, http://www.atmos-chem-phys.net/6/925/2006/.

Sander, S. P., Kurylo, M. J., Orkin, V. L., Golden, D. M., Huie, R. E., Finlayson-Pitts, B. J., Kolb, C. E., Molina, M. J., Friedl, R. R., Ravishankara, A. R., and Moortgat, G. K.: Chemical kinetics and photochemical data for use in atmospheric studies, Jet Propulsion Laboratory, California Insitute of Technology, 2002.

Shirley, T. R., Brune, W. H., Ren, X., Mao, J., Lesher, R., Cardenas, B., Volkamer, R., Molina, L. T., Molina, M. J., Lamb, B., Velasco, E., Jobson, T., and Alexander, M.: Atmospheric oxidation in the Mexico City Metropolitan Area (MCMA) during April 2003, Atmos. Chem. Phys., 6, 2753-2765, 2006, http://www.atmos-chem-phys.net/6/2753/2006/.

Shorter, J. H., Herndon, S. C., Zahniser, M. S., Nelson, D. D., Wormhoudt, J., Demerjian, K. L., and Kolb, C. E.: Real-time Measurements of Nitrogen Oxide Emissions from In-use New York City Transit Buses using a Chase Vehicle, Environ. Sci. Technol., 39, 7991-8000, 2005.

Sickles II, J. E.: Nriagu, J. O., Gaseous Pollutants: Characterization and Cycling, John Wiley \& Sons, Inc., 1992.

Stevens, R. K., Drago, R. J., and Mamane, Y.: A long path differential optical absorption spectrometer and EPA-approved fixedpoint methods intercomparison, Atmos. Environ., 27B, 231-236, 1993.

Stutz, J., Alicke, B., Ackermann, R., Geyer, A., White, A. and Williams, E. J.: Vertical profiles of NO3, N2O5, O3 and NOx in the nocturnal boundary layer: 1. Observations during the Texas Air Quality Study 2000, J. Geophys. Res., 109, D12306, doi:10.1029/2003JD004409, 2004.
Stutz, J. and Platt, U.: Numerical analysis and estimation of the statistical error of differential optical absorption spectroscopy measurements with least-squares methods, Appl. Opt., 35, 60416053, 1996.

TCEQ: Texas Commission on Environmental Quality, http://www. tceq.state.tx.us/, 2006.

Volkamer, R., Etzkorn, T., Geyer, A., and Platt, U.: Correction of the oxygen interference with UV spectroscopic (DOAS) measurements of monocyclic aromatic hydrocarbons in the atmosphere, Atmos. Environ., 32, 3731-3747, 1998.

Volkamer, R., Molina, L. T., Molina, M. J., Flores, E., Grutter, M., Galle, B., Mellqvist, J., Samuelsson, J., Knighton, B., and Jobson, B. T., Open-path emission factors derived from DOAS and FTIR Measurements in the Mexico City Metropolitan Area, Proc. of "Air Pollution as a Climate Forcing: A Second Workshop", http://www.giss.nasa.gov/meetings/ pollution2005/agenda.html, 2005a.

Volkamer, R., Molina, L. T., Molina, M. J., Shirley, T., and Brune, B.: DOAS measurement of glyoxal as an indicator for fast VOC chemistry in urban air, Geophys. Res. Lett., 32, L08806, doi:10.1029/2005GL022616, 2005b.

Wilson, K. L.: Water vapor interference in the UV absorption measurement of atmospheric ozone, University of Colorado, www.twobtech.com/Wilson_Thesis.pdf, 2005.

Wisbith, A. S.: Laboratory Study to Explore Potential Interferences to Air Quality Monitors, Prepared for the USEPA/OAQPS by Battelle Science and Technology International Battelle Contract 68-D-98-030, 1999.

Yanowitz, J., MCCormick, R. L., and Graboski, M. S.: In-Use Emissions from Heavy-Duty Diesel Vehicles, Environ. Sci. Technol., 34(5), 729-740, 2000. 